\title{
A Study of Physical and Chemical Properties of the
}

Fats from the Fat Lobes of the Moccasin (Agkistrodon Piscivorus) (Lacepede)

By

JOSEPH McLAUGHLIN, JR.

A DISSERTATION PRESENTED TO THE GRADUATE COUNCIL OF THE UNIVERSITY OF FLORIDA IN PARTIAL FULFILMENT OF THE REQUIREMENTS FOR THE DEGREE OF DOCTOR OF PHLLOSOPHY

UNIVERSTTY OF FLORIDA

JULY, 1949 
martw cor comprass

Page

\section{इस्मल}

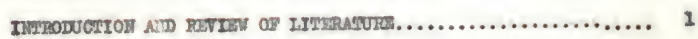

statement of Mosesrch Problem 1

Preperation of Noceasin Snaiks 012

Nethods of Seperation of the Jatty Mcids 2

Gualtative Investigation of component Jatty Melds 4

Preparation of Mred. Iatty Lolds from a Fat 5

Renovel of Unsaponlfiable Natter from the Mxed

Satty Molds 6

Renoval of the Ion Nolecular Welght Fatty Aclds 6

Chronategreph Absorption of $18 x a d$ Jatty Aclas 7

Son-Solvent Grystallization 7

Solvent Crystallisation 7

Separation of Polyothenola Aela s by Ithium Selte 8

Separation of Ured Jatty deids by Crybtalliation

Sron Solvents at Iow Ferneretures

DIㄴt1liation 8

Tractional Diat1Ilation of Fleher Jatty Meld Jutera

st Iow Pressures I4

Sorae Jeatures of the Caleulation of the Cormosition of Individual Eater Fraction $\quad 17$

Dotalis of the Method of Calculation Involved. 18

Jister-Iractions of the Hore Saturated or "Sol1a" Meids 20 
Inter-Vractions of the Vore Vnsaturated or "Llequid" sclds 20

Absorption spectra

The Identifleation of the Tatty lelds 29

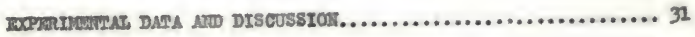

rable I 31

The sientficance of Fable I 32

ather-Insoluble Polyoromides fron Hoccasin Pat 33

Distiglation of Nothyl Iuter Jractions fron Ioecasin Jat 34

Teble II 36

Fable III 37

Table IT 38

mable 7

Table VI 40

Table VII 41

Table VIII $\quad 42$

Spectrophotometric Deta and its Invaluation

Proparation of the Allowine elycol Solution 45

Table IX 46

2able X 47

regure 1

D1 seusation of Figare 2

Determination of Hinolele, Linolenie, and srachsdonic 52 Melds in Voceasin Snaloe 011 by Spectrophotometric Analyeis 
Table $x$

Itgare 2

sonarar.

62

Fable $x 1$

Fable XII

pable XIV

concrusroms. 65 BIBI IOERAPIX. 66

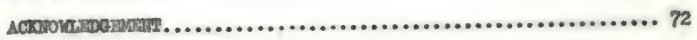

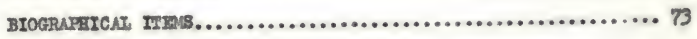

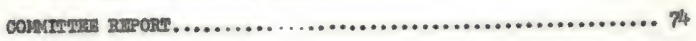




\section{PRIPACE:}

The material sontalned in this disertation is presented is a fomat sinliax to that used for the articies in Ghericel Reviess. Whis was found to be the most satiafnetory for proper Interrelation of the several parts of the irvestigation. The wanner of 11 sting seferences Is the cuatonary one for technical vorios in organto chevietry of conparable longth and scope. Journal abbreviation ate the offlciel ones of Onericel Abstracts.

In conforntty vith prosent wase in rosearch publieatlons, al1 temperatures are on the Centigrade scale. 
IXMODUGTO

ATI

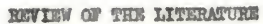


Snake oll, as uaed in this diseartation, refora to the glveeridos obtalnod fron the lat lobes of the moceasin. Thla resesreh project Involves a study of the chendeal and phrsicel propert1es of snake of protuced by cold-prossing the Lat lobes fron moceasin (Agiditrodon plsciverne)(Iseepede). Whe ohlef objective is a qualitative and quantitative analyats of the fatty acids present in moecasin wnatro oll.

Jor a mumnary of the vorte done on snake olls up to this timo, see data by Meleugenlin and Pollard ${ }^{1}$ and that of Iowns and Pollard ${ }^{2}$.

\section{Prapharton of Mocatsm swat or.}

The ortginal Investigations in thin laboretory, which were performed upon pooled sanples of heat-rendered o1Is, Indicate that hoatrendering produces some changes in the fatty ectes orleinalis presont. Cold-presalng of the fat lobes of an individual ppeoies fives an excellent naterial for investigation. On the basto of the previous research by Virtenghlin, Toung, and PoLlard, cold-pressed moccasin analce oll was deternined to be more denirable for use in this invest1gation of fatty acids.

The fat lobes of the spocies Aedstrodon piscivorus (Iecepede), comonly lonown as the Cottonnouth Hoccasin, wore maplied by Mir: Rose Allen of the Ross AIIen Rept1le Institute of S1Iver Springw, Florida. 
Upon removel of the lobes fron the snelses, the blood vas drained. off, and the fat lobes were arled on 111 ter peper. The lobes (in 25 exam quantitles) were vrapped vith extreme care in filter cloth so that the preswres ved vould not force lexge amounts of solids into the o11. Fhe 2iquid pressed out contalned smaloe o11, hemolgred blood, blood cel1s, vater, and some unbrolven fat cells.

A centrituge equipped vith two 250 e.c. contrifuge trabes ve operated at 1400 r.p.n. for two hours. Mech ran protuced about 350 grans of gurifled analce oil.

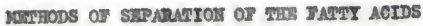

Present-atey lonorledge of the fatty acids is the culmination of mong years of study and research. To single foctor has contributed more toward this lmovlodge then the neary Investlgatlons whlch here been ande wot the seperation of the fatty selds. It is safe to concivde that irtore advancenent in this I101d wil be intimately associated with the devolopment of more effeetive nethod: for the seperation of those sctaิs.

The many proeessen which heve been imvestlgated for fetty acld separation, sach as crystallisstion of the acias or their derivativen, distillation of the aclds or their esters, and other nethode can be roughy diviced into two proupe. Whe Plrst of these Ineludes those processes whtch are useful for anelytical or ldentiflestion purpones only and which, Decause they are tine-conswuling or costly, heve very 
11ttle or no comercial applicstion. The second group consists of those procesnes which are adaptable to the large-seale preparation of the acids.

A reld clessifleation of the wothods for fatty acld soparation 1. not poselblo, since many of the comercial proeesses are also excellent labaratory procedures. Thtare reseerch wey corvert some of the nov strietly experimental methods Into comercialy fesulble processes. Among the procedares which heve boen swegested for the seperat1on. of the latty aclds are dist1111ng, erystallizing, and centrifuclug, together id th combinations of these nethods. Fo single procecture is ent1rely setiefactory for obtaluing yure latty acids. I combination of two or more procedures glves better results. This is perticularly true In the laboratory-acale separation of fatty acld nixtores, since a wum ber of erystaluzation are often combined with several fractional dist1Ietions. Generally the methyl enters of the acids are employed in the dist11lation procedures. The choice of the method of separatlon depende upon the starting material srailable and upon the objective to bo attalned. In the Lolloving alscusalon it appears logleal to conslder sone of the various unit processes separately. It should be realized, hoverer, that they ean Irequently be advantegeously combined and that the various nethode differ exeatly with regaxd to their practieal inportenoe.

Since this research is balled upon analytieal exrulnations of a natural fat, it seens desireble to incivde a discussion of the experimental wothods whlch have so far found acoeptance in the quant1tative or senl-quantitative study of tho naturel fats. A Ialriy full account 


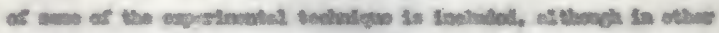

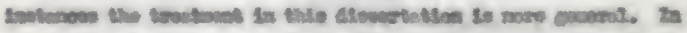

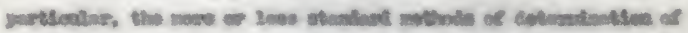

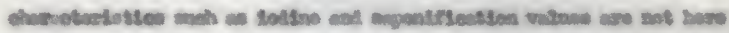

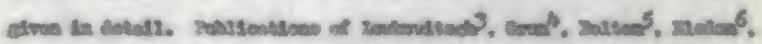

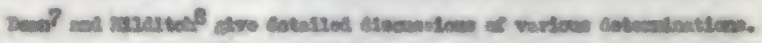

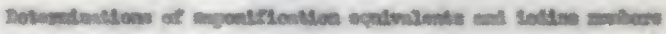

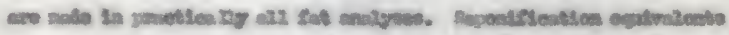

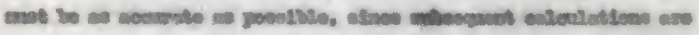

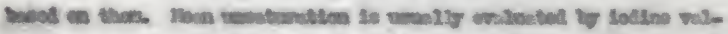

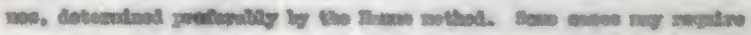

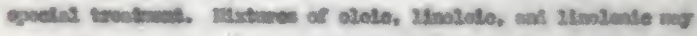

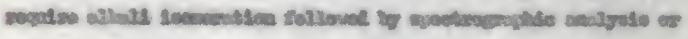

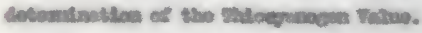

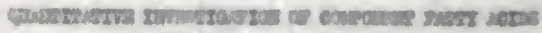

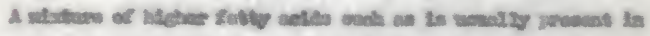

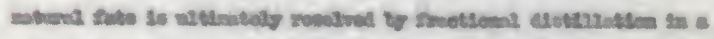

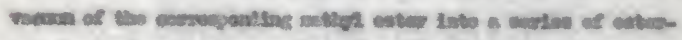

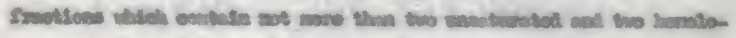

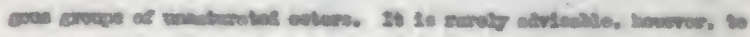

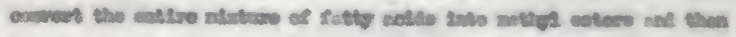

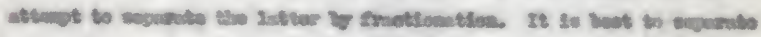

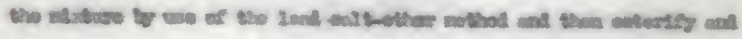
Atots.

$$
\text { tho }
$$


Differenees in the wolubilities of the lead salts of saturated and wheaturated fatty acids have been ut111zed for separation. Thls separation 1s simplipled 12 aclds of low nolecular velont axe abent. Jractional eryetell1zation from appropriate solvents at low tenperam tures may also be exploged for aeparating alaed acids.

Then fats contaln appreclable amounts of aclds of lover nolecular weight than actanoic (eaprylle), It is necessary to renove the more rolatile aclas of low moleculer weicht before proceeding to separate the higher saturated and unsatureted acids. Fhis only applies to mpecial typer of fate guch as milk fats and porpoitse ofls.

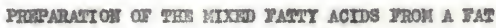

The quantity of fatty aclds required for an sccurate analysis depends upon the wuplexity of the mixtwre of component seids. The anount runs from 20 grass for a simple type of fat to 500 grams for a corplex type of fat wuch as I1ch ofls.

Conplete hydrolysis of the originel fat is essential. Fo appently 100 parts by velght of fat, add 30 parts by weight of potassium hydroxdie In about 500 parts of alcohol (95-100 per cent), rearlux for three hours, and then remove wast of the alcohol by distiustion. The soeps ase Assolved In water, and unsaponifiable matter is renoved at this stage, If necessary. The free fatty aclas are formed by adding wam, dilute hydrochlorle aeld. If unseturated acids are present in quant1 ty, care must be taken to prevent oxidation. Vhen the selds have been liberated 
they are extracted with other and are dried under vacuw at $100^{\circ} \mathrm{C}$. Imon highty unsaturated actds are present in quantity. It is not desirable to use too mech allenll of to prolong the saponlfieation. The hifhly unsaturated fatty acids oxliy undergo 1somerisation in the presenee of excess allowl and lengthy heating. Therefore, wh th weh aeld it is deelrable to use very 11 ttle allowi in excess of the amount theoret1cally required and to heat under roflux only as long as is required.

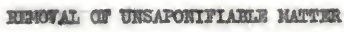

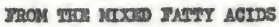

Wost, if not all, of the unsaponifiable natter present in a lat tends to pese with the other-soluble lead salts into the uasaturated or "21quid" Iraction. If the amount of unsaponiflable natter in the fat is less then 0.7 por cent, renovel is not neceessary. In the noceam 1n gnelos ofl, the rnseponistabie residue vas not remored sinee the amount wes only 0.46 per cent.

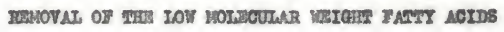

If approciable quantities of lover noleculax velent fatty aclde are present, they thould be remored before the higher fatty aclds are separated. One method of removing the lower nolecular welght fatty aeide is by distillation in a current of steem. 
The amount of low molecular velght fatty aclds in moceasin snalce 011 is lound to be very slight $(0.13 \mathrm{per}$ cent); therefore. It is not neceseary to remove the low molecular velight fatty aclds.

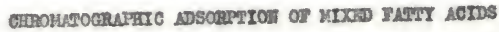

In this groblea tho use of chromatography appeared to offer no savantages over certaln other procedures.

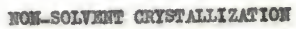

The non-solvent separation of the fatty acids depends upon the fact that the are completely miecible in the 11quid state. After the solutions are coolod, the hleher nolting actas cystallise, and they can be soperated Irom the Ilquid acids by ruitable nechanical means, such as pressing.

No completo Imentigation of non-solvent crystellisation is giren here since surflelent snake oll and equipment for lov-temperstrure voric were not evalleble. It is probable that nos-solvent erystallisation wovla produce a good separetion betreen the nonoethenold and polyethenold. actid present in snake o11.

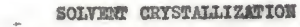

One of the best prelininary methods of separatine the varlous ecids 18 by the nse of the differing solubilities of the lead ealts of the 
fatty acids in other. Por a cosplote description of the techniquo used In the lead ast-ether method see the procoduse given by the A.O.A.C. ${ }^{9}$ and the work of MeIemghlen and Polland ${ }^{2}$.

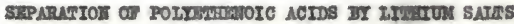

Coneidarable work has been reported in the 11terature concerning the separation of polyethenoid seide by the use of 2ithlum asts. The main solvent in use is the acetono-water solution. For a detalled sumery of this procedure see IIIAsteh ${ }^{10}$, Balston ${ }^{11}$, and Maricieg ${ }^{12}$.

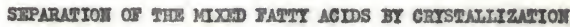

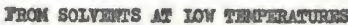

For a diseusiton of the savrantages and disadvantages of thl. method see Illatoh $^{10}$. Indtations of material and equipment preciuded use of the method in this atwity. Sepersation of fatty actas by lov-temperature, with or without solvents, is quite satisfactory then large amounts of fat are avallable. It use when the quantity of fat is quite anall is not adventageous.

\section{DISTILTARTOU}

The fractional aletiliation of fatty aeld eaters has been extenelvely aployed as a moane of separation of notural fats for enelyeis. The fractionation of the methyl estere is frequently used for the laboretory preparation of the Individusl acids. The most 1mportent earller studes 
concerned wth the fractionel alstilletion of fatty acids and tho ir esters are those reported by Irafft and eo-workars 13, who invest1 gated the bolling polnts of the actes and their enters under high vecuna.

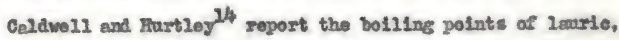
myrletic, peinitie, stearie, and oleic aclds in a eathode vacum, valng a Gaode prup is th a Croolces tube botween the recelver and jwep, and obtained values materially lower than those previoushy reported. These authors state that at a very 10 preserare a 11 quid has no bollIng polnt; it sublines or eveporates, Just as vater coes in air, at s rate and texpernture dependent upen the nature of the substanoe. Caldrell and Furtley elso ceseribe a method for fractlonstion of the fatty aclds of vatter and eoconat 011.

Exom ${ }^{15}$ describes an apperatus for the ast1ulation of the fatty celds at low pressures. The seperation of paladtio and stearlo aetas by racwen dist111ation ves reported elnwitanecosiy by refft ${ }^{16}$ and by Krele end Rasner 17 .

In 1906 the seperation of the fatty sclds of cocomt $011^{28}$ and of

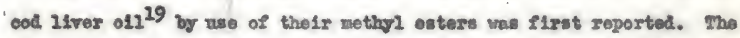
Iatty aclde of batter fat vere geparated by the fractional alst121ation of their methyl eaters, and $213 \operatorname{com}^{20}, 21,22,23,24,25,26$ reports the separation of the Iatty acids of both cocomat and paln losmel oll by a sinller method. The fractionel dist11lation of methy esters was also reported for the separation of Patty aclds of cotton-

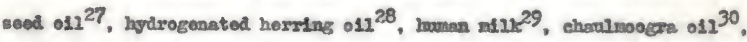


and peamet $011^{31}$. Stolroe ${ }^{32}$ deseribed the fractional dist1 Ilation of the methyl esters of cocomat ofl fetty aclds, and Aratrons. MIlen, and Noore 33 reported the separation of the fatty sclds of ooco-

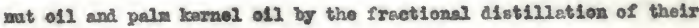
nethyl esters.

In 1923. Brown and Beal ${ }^{3 / 4}$ annenanced the separation of the wethy1 esters of the fatty acids of menheden oll by vacwu distilletion. mhey concluded that it 1 posstble to malce a rovgh separation of the sclds according to their noleculax velghts by this nothod. Iater Brom 35 stated thet the separation of the nethyl esters of the fatty aclds of brein 1ipoids any be wade by fractional dist1lation at pressures varylng Irom 4 to 7 an. The separation of the highly wnsaturated fatty acld of beef brains by fractlonal dist1llation of theix aethyl esters ald not succeed. Brom and sult ${ }^{36}$ atated thet It 1 possible to alstil Ireetlonelly the mothyl esters of the dobrominated aclds of eattle, hog, and shoep brains.

The laboratory separstion of fatty aclds (ar acids or as their esters) by the use of fractional distillation is considered to fire Incorplete separations. Channon, Drwinond, and colalns ${ }^{24}$ elat that the wethod In of 11ttle quantitative value. Sinod 1930 Imrestigation of the Iractional distillation of fatty add nixtures by use of methyl esters has been intensified.

Bquillbriw between the vepor and 11 quid phase is not obtained in the unpscliod colvums. Also, the reflux rat10 and the rate of dist1IIa- 
tion are not under control. Soparations performed in wuch equipment axe consegreently higly unsatisfactory. Improvenents in leboratory alstilletion apparetus are desoribed:by a muiber of invest1gatore $37,38,39,40,41$.

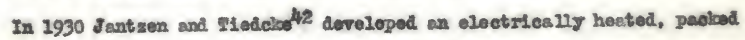
colwan which ras enelosed in an orrenated jecket to protect it against tempersture Inetuation. Thls agpastatus wall used In the eeperation of the methol esters of palaitle and stearie aelds, and the dorloe wes also orployed by these guthorw for the fractionstion of the hichmolting aelds of pesmat o11. The apparatus was anbsequentig modifled by later

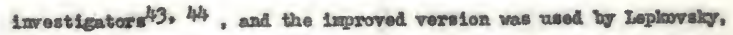

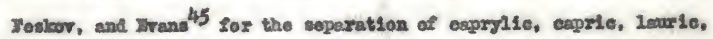
myolstle, palnitle, and emele acids. Indieations of association are obeerved In the separation of the hicher acids, but they could be cospletely separated as their nethyl enters.

Modern Iaboratory dist1llation apparatus employs an eleetriceliy

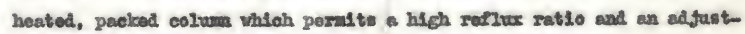
able d1st1Late collection. The colwan is paciod in a vell insulated outer shell to minlinge thomel Inotuation.

At tached to tho cormare a distiIling 1lakle, recelver, and cosdenser. Standard teper, Gxound-elass jolnts are uvual Iy enployed. The temperature at the top of the eolvim is measured by a thermometer. and the pressure is lnaloated by a menometer. The dist1lilng rlak and the colwan are electrical iy hoated, and a constent tenperature 16 maintained by rhoostate. The side arm is olectrienis hoated in 
order to prevent the distillate from solidifying. Low preserure is

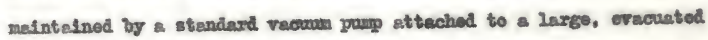

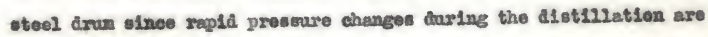
undesirable. The laboratcry colwms are usually three to sour leet In length and are permanently nownted. Their cifleieney depends largely upon the type of peoling vaterlal employed, rentwx rat10, ete.

Incustrial colwons are unally of the bubble-eap type. The varlous plates exert a ecrubbins action and thas give the effect of maltiple dist11lations. Folamp in the apparatrus 1s too great for Laboratory aistiliatlons. It is adaptable only to large-seale, contimuous wort. Peciced colvmas verally Glve materialiy leas hold-up and are quite

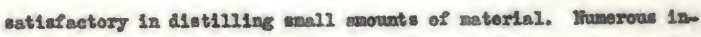
restleations of many different types of pecldne materlal hove been reperted. In 1932 Whitarore and Irux ${ }^{46}$ describod s colwm peolsod with Ieasing rings $(5 \times 5$ m. $)$ nade of 50 -mesh copper sereen; and the next year WII eon, Paricar, and Inughlin 47 deseribed a colwan packad vith a Blas: modifleation of the alngle and double-turn vire hallee which had been wed easlier. Weston ${ }^{48}$ reported a fractlonating colvun which was a nodilication of that deverdbed by Cooper and Fases? 1 .

The extensive Imvertigat1one of Podbielentak 49 contributed much to the development of effleient, mal-weale distilistion equipment: and nang of his revult were sumerlsed In his excollent artlele pub11 ishod in 1933. In thi article he deseribed his colwan and geve his recomendations for fractionel dist12attion. 
Ian 50 reported the separation of the methyl estere of palnitic. oteerle, olelc, and elasdie ecids by the use of the Podbielntak apperatus. Comperstive studies of Aiversified peciling neterial have been made by Ienske, Tongberg, and guigele 51 . These anthor state thet wire or slass helices, carding teeth, and Jack chalne vere found to be the best pacidngs.

The shape and distribution of the paciding materlal are important deterninative factorn in the efflelency of fractionating colvune. Hoverer, the ingortance of anch factors as the contect surface and the proper drain-back cannot be orer-emphasiged. Tongbers, Gaibsis and Fenske 52 cescribe an efflelent Iractionsting colwn pecked if th ono-turn glass hollees. Preldng natertal composed of viro hollees is clained to be extrenely efflelent $53,54,55,4$ colwan pacldne of close-fitting wire helloes was ued by schoenhelner and Rittenberg 56 for the fractionstion of nethyl palditate Irom nethyl stearate.

The we of fatty aeld ester dist121ation mothods of fat analysis wes reviewad by Iongenedbur 57 in 1940.

The conicel type of paclding was deseribed by stodman $58,59.4$ detalled description of this type of paclelag and results of minbers of effleieney testa were given by Brase ${ }^{60}$.

In recent years the nse of the nolecular still has been of frest inportanee in fractionating very high-bolilng mubsances. Nolecular alst1liation of the hichly unsaturated aclas of 11 oh olls vas reported. by Pamer and Van den Fleuve1 61 . 


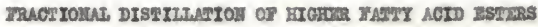

As row prassuras

As alreedy stated, those pertione of the nixed fotty solds which are to be further realved by ester-fractionation are converted into methyl esters by bollins with about fow times their velght of methel alcohol in the prevence of spproxdmetely one per cent by velght of concentrated sulfurle acid. The unesterifled seld is resoved by vashing the ether solution of the esters vith aliute potassiva cerbonate colutioa. Whe comversion into methyl estere is umally $92-98$ per oent erfoetive. If production is below this Iigure, the westersPled sold should be recovered and re-esterifled.

The mothyl esters are used prinerily because of their elight 1 y lower bolling polnts as compared with those of ethyl estars. With the operating pressures renglng frow 0.1 to $0.2 \mathrm{~mm}$. now readily obtelneble with the ordinary rotary oll proupe, this feotor is 1 se alguslesnt then forworly. Fowever, it is courenlent to continue uslng the nethyl esters since so much deta already have been recorded. Lor wethyl esters.

The recorded bolling polnte st the head of the sractionsting colvun are not of selentifle elenifleaneo in this tgpe of aistillat1on. Foverer, the colnum head temperature should be systenatlealiy recorded; since, In confunction with those of the heating bath, they afford a rellable indiestion of the smoothness of operatlon, and therefore of the efflelency of the fractionation. 
At 0.2 mun. preasure, the columa head temperatures for methyl 1aurate, wethyl palmitate, end wethyl oleate (or atearate) are approxdmately $75-80^{\circ}, 120-15^{\circ}$, and $130-135^{\circ}$, rempectively.

Inless a large fraction of lanom range is being collocted for roIreationation, the wolisht of any one enter-issotion ahould not greatly expeed about ten grans and aeg be as 11ttle al two or three grans. Dven when It is reavonebly certain that a mixture of eonstant composition is af stilling in laxge quantity. It is better not to excesd the amornt statod. Brrors in the aneigticel determination of soponifieation oquivalents or Iodino Values ere minimiged if cerried out on several

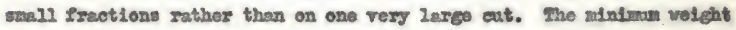
of a frection is deternined slmply by the enorat required for sccurate doternthation of 1 ts enelytieal characterist1es.

The unsaponiflabie or non-fatty metter geaerally renalne in the restarral, undistilied ester frection. The emornt of ranseponiflable resiche mey be dotermined ty renoving it from the elloaline solution - obtained after deterulnetion of the epparent equivalent of the residual ester. Whis is followed by recovery of the fatty selds and redetermination of their equivelents. The exount of esters in $\mathrm{I}$ grems of a residurl ester is thens

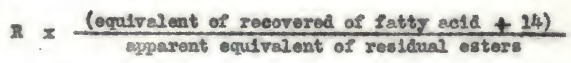

The effect of heat upon unseturated fatty esters during the Iractionstion is reported by Forris ot $1^{62}$ They report that estero of acids 
with three of fower weonfugated double bonda are substantially wheffected. It is their opinion that nore unsaturated polyothenolds (e.8. Iish oil) aelds are also ilttle altered, although silght reerrangenent to confugated isomerides, folloved by some dimerisation, noy tein place to a very small degree. Ay materlal so altered eppeare In the residual, undistilled esters, These authors concluded that the ehanges Indueed in the course of a fatriy prolonged distiliation vere insigaificant. They state that the action of reagents (alkel1) and solvents during hydrolyels and treatment of the fats prior to fractionatlon is a mech more important potential souree of stractural alteretion than any condition enoountered during frationel distiliation at low presereres. It abovid be polnted out thet esters of confugated higher fatty aclds undergo polymerisation and/or eyeligation at the teanperature at which they distill. In heated fraetionation colunns of the doscribed type and thet such eaters (e.g. methyl elaostearatea) cannot be distilied in a colum at too high a temperature.

Worris and Terrg ${ }^{63}$ gave the preclae bolling polnt data for the folloving esters at one m. pressures methyl woslstate, 124\%; wothyl palid tate, $136^{\circ}$; methyl stearate, $155.5^{\circ}$; mothol oleate, $152.5^{\circ}$; and methyl Inneoleate, $149.5^{\circ}$. Althouse and Frlobold ${ }^{64}$ also reported some date on mothyl oleate, methyl 1ineoleste, and methyl 2inolenate. They elatin that the boiling polnt of the three $\mathrm{C}_{18}$ actd methyl enters are In reverse order from that Gdven by Jorris and Terry. All agree that the boiling polnts of all. three of the $\mathrm{C}_{18}$ eali methyl eatera are extremely elone. 


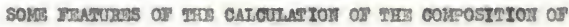

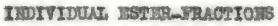

The purpese of the ester-fractionation procedure is the production of a series of ester-fractions sor use in the analysis of a watrure of fatty seids. Fech of these estex-fractions shovid contals not nore then two unsaturated esters. The conposition of woh fractions can be directif calculated from thois saponifleation equivalents end Iodine Values. Fhis 1s true of wost fats in whlch the only unsatureted components belong to the $\mathrm{C}_{18}$ serles of acids (olele, Iinolete, and Iinolente). When, sa is umally the case, both olele and Inoleie seids are present, the mean Lodine Value of the $C_{18}$ unsaturated esters can be deterainod. llocept for a negliglble exrox, It aen be essumed that the distillation of those esters is proportlonelly constant throughout the operetion.

The bolling point of methyl Iinoleate is very elose to that of aethyl oleate. If inolenle seid is the only poly-ethenold actd prasent, a complote deterzination of vuch ostermfrectlons may be nede. The deterzinetion ney be mede by use of Iodins Value and wapontflcation equivalent in confunction w th the spectrophotosetris deteralnation of the linolele acta.

In some 1ats, eapecieliy those from aquatie sourees, the nlathure of unsaturated acies, pertienleriy in the $\mathrm{C}_{20}$ and $\mathrm{C}_{22}$ series, is very conplex. The constitution of mang of the poly-ethenold aelds is stiul uncertain, and it is nocessary to adopt a different method of evaluatine the enter-fractions. 


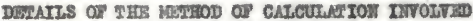

As already stated, the conposition of an ester-fraction which contains esters of only two sturated acids w th the unseturated selds 211 of the same cerbon content can be deduced fron its equivalemt and Iodine Value by comparatively simple celculation es followe:

If a fraction of weight $w$, equiveleat $I_{v}$, and Iodine Value $I_{v}$ contalns a veight $\mathrm{t}$ of unssturated esters (of the sane cerbon content,

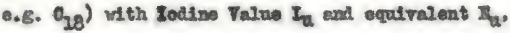

$$
v=v\left(\frac{I_{v}}{x_{v}}\right)
$$

and the nean equivalent, $z_{8}$, of the saturated esters $(u-n)$ present Sollows eron the equation:

$$
s_{s}=\frac{v-u}{\frac{v-\frac{u}{4}}{\frac{1}{4}}}
$$

Fron $\mathrm{z}_{\text {s }}$ the welghts of saturated esters are celewlated al $\mathrm{B}$ Bnary nfiture of the honsolegues (e.G. $G_{16}$ and $c_{28}$ ) between the equalvalents of vhteh $B_{\text {s }}$ I1e.

Again, ester-fractions whoh inolude only wnaturated derivatives of celde of two groups in the homologous serles ean be ovaluated alrectly fron theis saponiflation equivalent. In certain cases the cosprotatlons becone somentut nore couplicated, since the velfete of more then three Independent components are imolved. 
If $x, y$, and $s$ are the respective volghts of the one saturated and the two ansaturated esters in a fraction of weight $w$, and $z_{x}, z_{j}$, $\mathbf{I}_{\mathbf{z}}, \mathbf{I}_{\mathbf{W}}$ are the corresponding equivalents and $\mathbf{I}_{\mathbf{y}}, \mathbf{I}_{\mathbf{z}}, \mathbf{I}_{\mathbf{V}}$ are the corresponding rodine Talues, then

$$
\begin{aligned}
& \text { (1) } x+y+z=v \\
& \text { (2) } x / x_{x}+y / y_{y}+z / x_{z}=w / x_{v} \\
& \text { (3) } z \cdot I_{y}+z \cdot x_{z}=w \cdot x_{w}
\end{aligned}
$$

(In equation (2) the saponification values $\nabla_{x}, \nabla_{y}, \nabla_{y}, \nabla_{V}$ ean be used If desired, the equation becoming:

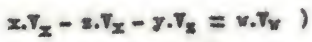

The values of $y$ and $s$, the unsaturated components, are thas determined whle, fron that of $x$, the blnaxy wisture of sathreted esters is evelusted airectis szon its equivalent $\left(x_{x}\right)$.

It mey be pointed out that, In nse, the equations (1), (2), and (3) can be convenient is simplified is employlng in equation (2) the rectprocal of the equivalents times $20^{6}$.

The proper method of evalustion of the eater-frection data in any given case depends upon the particular elreunatences. In the mefority of anelyses, If the more efficient type of frectlonating colwm has boen used, It is not necessiry to isolate and dotermine the equivam lent of the saturated corponents of an ester-fraction. 


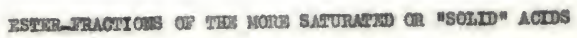

The lead selts of totrem and horomdecenole aeld are Ireoly soluble in ethox. Since the manil Iodine Values in frections of equitralent below 296 mag be attributed solely to wathy oleste, tho celculation is stralght-Somtard. This wethod has been reed when "solld" evters have been alatilled vith a ingle distillation apparates.

when the electricely hosted colven is exployed, It is evident that traces of these seids are dotectable in the $\mathrm{O}_{14}$ and $\mathrm{O}_{16}$ esterfraotichs. In wach eases it may be aserumod thet the saturated and unsaturated portions of the fraction have the sane equivalent.

In Instances in which the seturated estors of a fraction have been Isolated and their equivelent deterrined, the general equations given in the proceding peracraph ma be used with $\mathrm{x}$ at the veight of watureted enters of doterminod equivalents, $\mathbf{X}_{\mathrm{x}}$. The dotermined equivelont $\mathrm{g}_{x}$ way then be used to calevilate $x$ as a blnary mixture of satur ated esters.

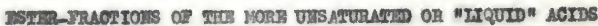

In Irections with equivalents below those of unsatureted $C_{18}$ eatere there axe some peimd tates and mech larger smovnts of agristates.

The saturated enters present in these frsetions mes bo isolated and the composeats calevieted by the general equations glven. If an erficient fractionating colvin wes used, celculatione of the esterfractions of equivalent below 270 on the assumption that thetr 
satureted and unsaturated parts have the sase equivalento 18 wurf1clent.

3ster-fractions with equivalents botween 270 and 290 are ealcolated from the general oquation. They are ealculated all mixtures

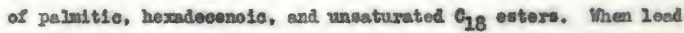
selt-ether separation has boen anployed, the prosence of stearie eeld In the "Iiquid" pells way be conntdered to be of little ingortance.

Iractions consisting wholly of unsaturated. $C_{18}$ estexs should, be evaluated in th the fonlowing facts in atind

So lons as the unsatureted 18 esterwiretion consiste meinly of oleate, with not more than 10 to 20 per cent of 11noleate, the determined equivalents correspond elosely with those deduced from oleate and IInoleate Iodino Values.

When the estermirections contaln large proportions of Linoleste, the determined equivelente of unsaturated $\mathrm{O}_{18}$ ester-fraction tend to be appreelably lowex than those observed by the lodine values.

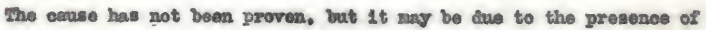
traces of sutobxtalsed ooters vhich heve undergons solsalon curing refluxing with alcoholie potsesium hydroxdd. It showld be bome in alnd that the cetermined equivalents of the more unseturated $C_{28}$ ester Prations are uspally eliehtly lover than the true values. 
In ester-iractions Imealately preceding those which eonsist wholly of unsatureted $C_{18}$ estere, there are very gmall enounte of satureted esters. Actual calculations of the mean equivalents of these enter-fractions grove clepleurt, and resurts are not too rellablo. It has been found that is is botter to eredit then as palntate than to nse their deduced ecrutralents.

When only linoleste and oleate are present, the proportion of each followe Alrectif from the lodino values.

Fractions vith squivalente above those of wasturated $C_{28}$ mat be ealeulated to binsy adxtures of $C_{28}$ and $C_{20}$, or $C_{20}$ and $\sigma_{22}$ ' sccorking to thats observed equivelents.

In ept te of the monerous varlants and escuingtion vuesested in the preoding paragrephs, it has been found that rellable analywes ney be obtained throut calculation of ester-fractions. Iech case mast be considered upon Its mersts, and the celculation should take Into account the nethyl esters present in the aixture. The ensigres of the nore unsaturated frastionshould be conpleted quickly, and eare should ve taken to avola oxlastion. With proper preceutions, it is possible to obtaln component seld data of the order of socuracy ind1eatod bolow.

Harlng determined the approxinate conponents of each fraction, It Ia a conparatively simple matter to obtaln the composition of the "solid" and "Liquid" esters. From this it is possible to calculate the enownt of esch fatty aold present in the orielnal sample. In the case of 
complex fats the operations are cxtremely lengthy and tedious, and a IInal accurecy of not more than 12 wits ney be reached. In this calculation.

Iren ith the somemat greater Inaceurecy of the flewres for sone of the more hichly vneturated components of sish and allsed fats, It has been clalmed that the accuracy is comparable with that for many other natural produets of a comparable complexity.

The "11quid" fatty selde obtained in component acid analgeis should be converted Into nethyl esters, and thelr fractional aistillam tIon carried through without delay.

Onless due preentions ere observed, selds of the nore wnseturated type are 1isble to undergo polynorle or other chenges during the estorlfleation. This hes been shom to be especlally $11 \mathrm{kaly}$ to oceur dwring concentration of the minerel acla by removal of the nothyl alcohol. In sueh instances it is necessary to (a) arploy the ninlmum concentration of Bulfurle acld to secure neerly complete enterlfieation (probably as 11 ttle se $0.5 \mathrm{per}$ cent), and (b) ressove no wnchanged methyl aleohol by dist1uation, but to pous the reaction mixture into cold. veter and proeeed at once to extract the esters Irom the dilute aleohol wh sther. The latter precation is very important.

The "Bol1d" selda obtained In separations carried out as above conteln the whele of any steerle or higher saturated acids present, nearly all the paintt1e scid, a considerable proportion of any myristie acld prosent, and smaller propertions of any lower saturated 
acids. They will also include, of vnsaturated aclde, minor percentages of oleic seld. Nono-ethenotd ectds of tho 96 or lower sertes, and polf-ethenold aclds of ans cerbon content vill, on the other hend, pass alnost entirely into the "Iiquid" ecld group.

In adaltion to nearly ell the olole acld present, the miquid" actds nay inciude most of the more unsaturated actas of the $\mathrm{C}_{18}$ or higher serles; the monomethemold solds of the $c_{16}$ or lower sertes: mach of the saturated $\sigma_{8}, C_{10}, G_{22}$, minor anounts of myrist1e; and treces of the palnitio.

\section{ABSORFIOI SPCHRA}

Oring to the presence of the double band in the esrbonyl Eroup. the saburated latty sclis shov a typleal absorption spectrus. The ethylente acide not only exchtbit an absorption due to the cexbonyl group but also show characteriet1e ebsorpt1on valuea dependerst upon the ramber and the relative positions of the donsle bonds.

since the witravielet absorption propertios of the seturated Iatty aclds are dependent wpen the presente of the chrorophorle carbonyl eroup, It If evident that the absorgtion cherecteristice of the satruratod aclas should be qualitativaly elnilar. Romart-ineas and asociated 65 invest1gnted the vitra-violet absorption properties

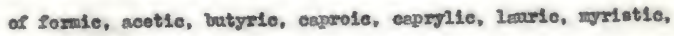
palmit1e, end atearle acide between the ware lengthe of 2000 and 2555 Angstroms. They stated that the absorption coeffielents of 
the hifher nembers are essentlally similar. These cathors concluded that since the length of the chain does not materially affect the absorption coefflelent, methyl and sethylene gxouph cannot be colnsicered as elfronophores In this regton of the spectrue. Bleleold and Henri ${ }^{66}$ hed studied a mumber of saturated ecids in the range 2144 to 2600 ingetrons earlier and hed contended that an ineresse In the length of the hydrocerbon ehain was attended by a shift in the aboorption band toward the red and elso by an ineresse in the menttuale of total absorption. Hoverer, Leg and Aronds ${ }^{67}$ stated that this generallsation does not apply to the hichor saturated solds. Durx and

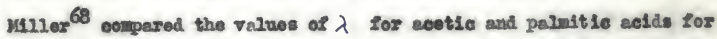
verieus velues of the nolecular extinction coeffielent.6.

Studies of the absorption coefflefents of the saturated acla have led to the postulate that in the 11 gard state the aclds exdst in a dissocisted and in a non-dissociated forn 69,70 . Ister formation does not naterisuly affect the cherecter of the sbeorption curve. It has been shown that the values of the vartoul esters alffer only. illghtly Irom those of the parent acids66, hut absorption is realear Iy changed by salt formatson 67 .

Unssturation in the hydroearbon ohaln produces a chenge in both the Intensity and the position of the abeorption bends, the absorption belng due not only to the carbongl group al also to the etholonic bends. Conjugation is attended by a marbod. ahift in the absorption band tovard the red. Thls phemomenon recentig hes been the subject of 
extenglve study and has been proposed for use in distingulshlng conJugated from uncomfugated eclda or esters $7,72,73$. Liter a study of the abserption spectre of unwaturated acdis van der Evatat $7^{7 / 4}$

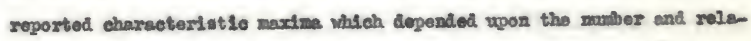
tive positions of the othylente bondw. Dingwe 11 and thompson 75

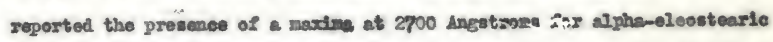
seld. In isolated double bond between carbon stones produces an ab-

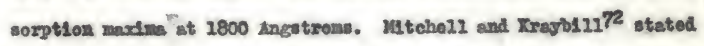
that from theoretical congidarations, absorption bends in the spoctrel reglon of wave lengths longer than 2200 Angetrosus are not characteristie of non-eonfugated inoloie or 1inolente sc1d. Bare and 14uler 68 recently extended the abeorption studies of the unsatruxated acid to 2100 Angetrone and noted that the vnsaturated sesda gave an abeorption carve that is a combination of the saturated acld absorption curve plua on sbeorption ourve two to the ethylonic group. The new band for alele sela oecurs at a lenger wave length then that observed sor $3-$ heptene, and conpertson of the absorption spectra of olelc, 1inolele, and IInolonite acids shove that the addition of etrylente bonds prodwoes a further shlft of this chareterlstic bend toward the longer vere lengths.

Doternination of the Infraxed apeotre are frequentig useful in

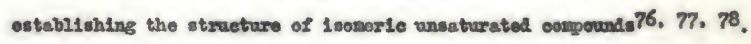
C1s aeids show a strong infrared absorption, but this absorption in absent in the trane forn. 
Strdies of the ultraviolet sbsorption apectra of the setwrated Latty aelde and of olele, linolele, Iinolente, and arachidonle acide have been extended to 2100 Angstrons by Dury and associatea79. Since none of the unsetrrated colds reaches a peale st 2100 Angetrons, these studies were lster extended to the extreme vitraviolot; and many Interesting observations were male 80 . A comparison of the abrorption ppectra of myristle scid dissolved in othanol, 1s0-octano, and heptane show that the polar solvent, ethanol, shifts the absorptlos naviunam to a lever weve length and gives lower abeolute values for extinetion coefficients. II the wetrurated aeids have a brode band with tho nexdrum at about 2050 Angatrom and an intense sbsorption botween 1850 and 1730 Anestrons. Vnsaturation in the fatty acids prodnces absorption sinilas to that of the unsaturated hydrocarbons. Blatdinisation of olele ecli shlfts the abeorptlon curve toverd the visible ond of the spectrum. The avallable apectrophotosnotrle data on the fats, fatty" aclds, and thely osters have recently been comp11ed ${ }^{81}$. Brice ${ }^{82}$ contimed his research on exlsting spectrophotometrle nethods, nodfled for applioation primarily to the atection and estination of 30 proportions of confugated and non-eongugated conponents in fats, 011s, and sogps. The nethod is also applloable to fatty interlals having high proportions of those conponants. Modifleatioas incivile corrections for absorption by interfering

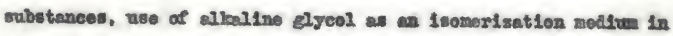
the analytical procedure, and corroction of absorption data on the 
Isomerized product. The absorption dats correction 1a neaded to conpensate for the absorption in confugated corgonents mich vere in the raterial bolore the imonerization.

Results on sone nev spectrophotometrle analyses of letty aclas vere reported by 01Coanor 83 , 84.

In 1946 Iandberg 85 stated that these vere varlous gpectrophotom netrle cherges in fats turing rencldifleation.

Turther work has been done on the spectrophotometric etralios of the oxddation of Iats through the oxygen absorptlos and ehromophore produation in fatty esters. Folnex 85,86 investigated the relationship of exrgen sbsorption to absorption bend derelopment in the ostern of the comson unsefurated fatty selde. The cats reported anst be evaluated earefully before any conclustons sre reached.

Beadie ${ }^{87}$ recently priblished a nethod for the use of vitreviolet speetrophotonetry in the study of chenges in the couble-bend system of fatty acids. His procecture is clained to be of spectal help in cases where both eonfugeted and nox-confugeted coingononts oecur.

milditch and Shrivastere 88 reported that the determination of 11nolente cold by the spectrophotonotric nethod geve a hicher value then the enount of 11 nolente acla present should gito. Wo explanam t1on wae offored for this exeess over the true values.

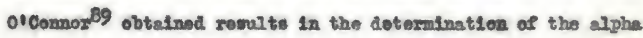
and bets isoners of elseostearle seld In trang oll by the use of a 
spectrophotonoter. The regults obtainod Irom apeotrophotometrle and chemical analyees vere not in complete agreement.

In 1948 Ienarickson et 21.90 discussed the epplication of vitreViolet spectrophotometry in arying oll reseerch. In their ext1cle they traced the developnent of tests for the determination of fatty acids to gpectrophotomatrie nethode.

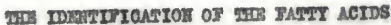

The methods used for the 1dent1fleation of prure orgente comperinds and for ascertalning the components of alxtures are generally fentur to al chemists. Physical consteuts such as the nolting points, rafrective Indices, and speelfle grevities are unfrorterly recosnized as contributing to the identifioation of exganie compounds. The preparation of a charecterislng derltative frequently offers furthor proof of the identity and pratis of the compound in question.

Unforthanately, very few acceptable derivatives of the dinstrureted fatty acids herv been cescribed. A mumer of investlgators have developed derivatives of the saturated aclds which here proved to be very useful in the identiflestlea of these eompounde. The close atructurel sinlarity of the various series of fatty aclde has made posstble the rse of a mutber of analyt1eal procedures whlch heve proved to be of creat value.

such constants as the neatralisation equivalents, the Iodine Funber, the acetgl value, and the nore recent thloeganate wuiber are 
well-bown teras whlch have been applied to the fate and fatty aclds for nawy years. Without stterpting to detract from the usefulness of mach ansiytieal constants, it ahould be pointed ont that they are not, per se, proos of the Identity or purtty of an indivianal acld. For Instance, an equinolecular mixture of paleitic and stearle selde w112 pessess the neutrallsat1on equivalent of nargarle sold, and a inture of wnsaturated sclds mos posseas the theoretieal lodine muber of olole seid. 
IXPARTOWWI, DARA AW DISCUSSIOI 


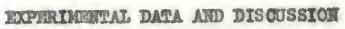

\section{TABRI: I}

Data on 011 fron Cold-Fressed Fat Lobes of Nocessin (Apldstrodon Piscivoras) (Inacepedo)

Nolsture and volat110 Matter. . . . . . . . Ioss thran 0.2. \&

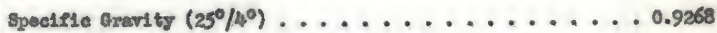

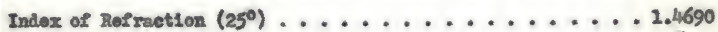
Seponification llumber (Koettstorfer number) . . . . 192.6

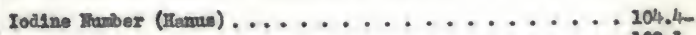

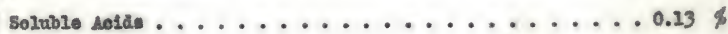

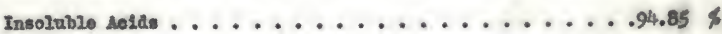
Relchert-lielsel value (Soluble volatile Melas). . . . . 0.07 \& Polensiso Value (Insoluble volat1lo Aelds) ....... 0.04 \&

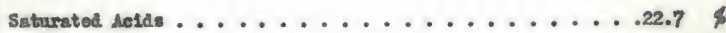
Unsaturated do1as ......................... \$

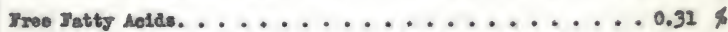

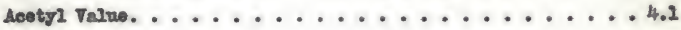

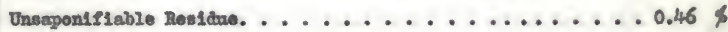

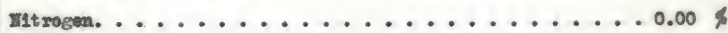

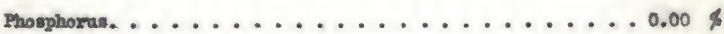

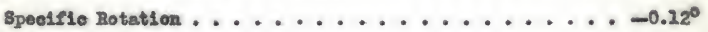

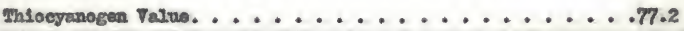




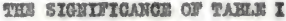

Fron the date in Fable $\mathbf{x}$, it is seen that the senount of soluble aetds is 0.13 per cent, the solvble volatile aclds ere 0.07 per eent, and the Insoluble viat1le aclds are 0.04 per eent. This Information shows that the amount of low noleculas volght fatty acids in moceasin snake of is very low. Iow moleculer welght fatty acids mean tho ae selds of Iower molecular velght then lawrie acid.

The unsaponflable residue is Importent since the amovint of higher molecular welght alcohols present is shoun by the quantity of the realdue. Data Indieate that the anount of highex molecular veight nleohola (of the choleaterol type) present in moccasin anatre oll is 0.46 per cent. Several color tests mun on the wasaponiflable matter whov that cholesterol-type alcohols are present.

An acetyl value of 4.1 was found. This value 1 actually the "epperent scetgl value" rather than the true acetyl value ${ }^{3}$. Apter subtractine the acetylation cue to the Iree fatty acid, the scotylam tion ane to the Iree hyliroxy groups of the gigoerol (produced then the freo fatty acid vere Iorned), and taldng into account the experimental error in the deternination of acetyl veluos, it was found thet the "troe acetyl value" Is vexy sand1. It is evident that the anount of hydroxy aeld.s present in moceasin snake oll is very s11 ght. The acotyl value is uaed for the purpose of deteralning the amouat of hydrox scids present in noceasin snalce ofl. 
It should be polnted out here that the difference between the Iodine Value and the thlocyanogen velue of en unsatrarated ectd nixture is a neasure of the poly-uneatureted actde present ${ }^{91}$. Since the thlocyanogen value of the nocesein snolon oll is 77.2 and the Iodine Value of the noecasin snalice 012 is 204,4, it is apperent that the enount of polymuseturated seids present should be about 26.8 per eent. The

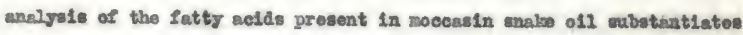
this fluding.

It wast be polnted out that tho lodine muber of a colnpound is not alvey" a true pescure of its unscturation. An excentnation of the theory behlnd the use of lodine mubers in deternining the wnseturation of dfferent coupounds shoved severel inportant factors. Reporte have stated that confugeted double bonds fasl to efve the theoreticel Lodine namber and that the distence of the double bond from the cerboxyl and the wethyl exoup in any acld affects the lodine addition.

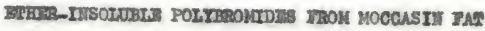

The percentege of ether-1nsoluble, polybromides, deterwined ss

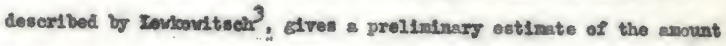
of unsaturated $\mathrm{C}_{20}$ end. $\mathrm{C}_{22}$ fatty aclas. From 63 grans of milquid" acid (obtained from the lead saltwother wethod of separetion) there were produced a total of 15 srabs of ether-1nsoluble polybromades. Trom this untore of polybromides vas obtalned a fraction valah began to blacken st $200^{\circ} \mathrm{C}$., and on further hestlng the sraction decouposed 
on furthes heating. Meoorilng to Tevicovitech, this is typleal of arachidonie acid. When Iowisoultsch nede this atatement it was thought

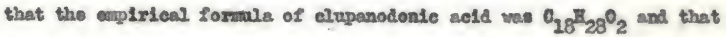
of arachiconte cold wa $\mathrm{C}_{2} \mathrm{O}_{32} \mathrm{H}_{2} \mathrm{O}_{2}$. At the present tine the emplrical formala of elupanodonte ectd appears to be $\mathrm{G}_{22} \mathrm{I}_{34} \mathrm{O}_{2}$, end thet of artichidonse acid is still considered to be $\mathrm{C}_{20} \mathrm{I}_{32} \mathrm{O}_{2}$.

On the basis of the anount of ether-issolubie polfferonides obtainod. It was erlourlated thet the oriftnal snake 012 contrins st least 7 per cent of the $\mathrm{hlohly}$ unseturated $\mathrm{O}_{20}$ and $\mathrm{C}_{22}$ fatty aclds.

It shoula be pointed out that the ether-1nsolubin polybromiles do not_alvey give the actual quantity of the highly unsaturated $0_{20}$ and $\mathrm{C}_{22}$ fatty acids present 92 .

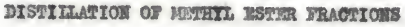

MrON MOCCASTY IAS

ILfty grasus of "11 equal" fatty ac1ds, obtalned by the use of the lead-aeltmother method, wore added to 200 exans of nothenol and 3 grans of concentrated mulfurle acld. The mlxture vas bolled for about flrteen mimates, and then the excess methenal distilled off unt11 about 80 per cent of the methenol was removed. The of xtruxe was then porured Into 1 21ter of alstilled vater, and 200 grems of ether vere sdded. The ether lager vas then washod vith a dilute wolution of potasalum carbonste. Ifter the unrescted fatty ac1ds had been renoved Iron the eaters, by washing repeetedy wth potessiwn cerbonate solution, 
and the other va alstilled off, leaving the methyl eatere. A 92.4 per cent conversion Into the nethyl esters regulted.

The date in Table II were obtalned when 45.3 gram of wethyl enters were alstiled at about 1 ma, presaure in a Iocky and Inre1193 type colvuan. The nethyl esters were obtained Irom the "11quid" ac1ds separsted by vee of the leed-salt-ather prosedure. Whe distillation fractions vere exanined for refractive indices, saponification equivelents, and Iodine Values. With this informstion it was possiblo to use the Flialtch mothod of calculation for the composition of the Individus 1 ester-iraet1ons ${ }^{8}$ accordine to the procedrure a discus ad In the review of the ilterature. 


\section{TABIE II}

Date Obtained Irom Dist11lation at 1 m. of 45.3 Grans of Methyl Ister of "Isquid" Mcids.

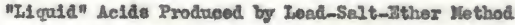

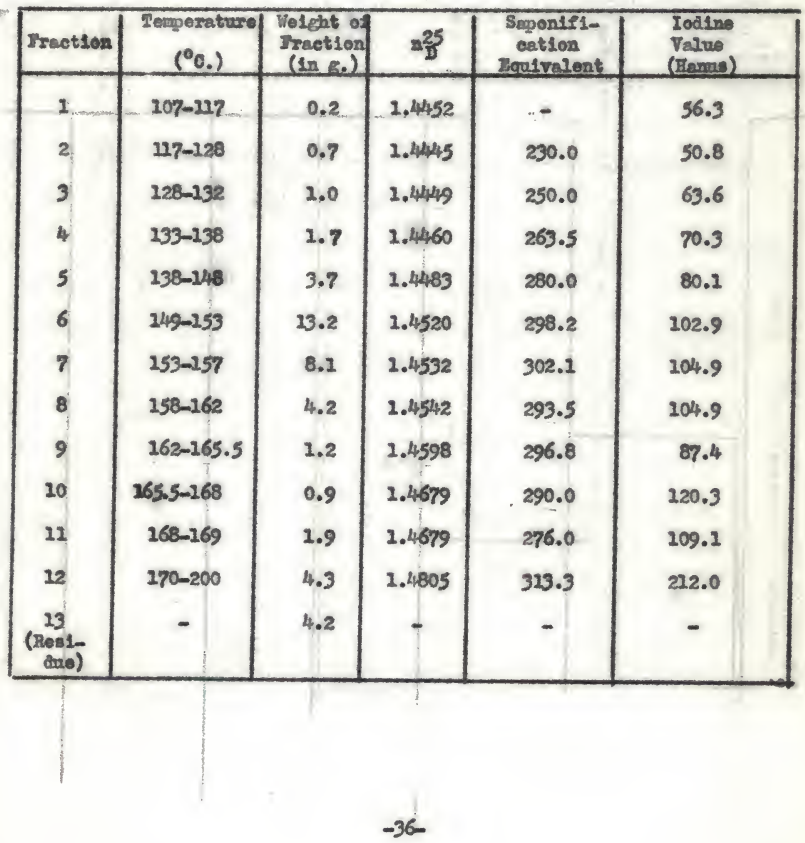


Inow the seponifleation equivalents, redractive indiess and Iodine Mumbers, the brealadown of the varioun Iractione are fiven In Table III

\section{TABIS III}

Eater Composition of Fractions Obtalned from Dist1lietion at $1 \mathrm{~mm}$. of 45.3 grame of Methyl Ioters of "Iqquid" Malds. "Iquid" Iclds Produced by Iead-SeIt-Ether Mothod

\begin{tabular}{|c|c|c|c|c|c|c|c|}
\hline \multirow[b]{2}{*}{ Sermple } & \multicolumn{7}{|c|}{ Anount of retere (1a g.) } \\
\hline & $\begin{array}{l}\text { Wolght } \\
\text { of } \\
\text { Iraction } \\
\text { (In } 5 .)\end{array}$ & \begin{tabular}{l|} 
Rethyl| \\
norist \\
ate
\end{tabular} & $\begin{array}{l}\text { Dothoy } \\
\text { pelnit } \\
\text { ate }\end{array}$ & $\begin{array}{l}\text { Wothy } \\
\text { hexee- } \\
\text { docen } \\
\text { oate } \\
\end{array}$ & $\begin{array}{l}\text { Methey } \\
\text { oleat }\end{array}$ & $\begin{array}{l}\text { Vethay } \\
\text { lino- } \\
\text { late }\end{array}$ & $\begin{array}{l}\text { Nothol axachif } \\
\text { conste } \\
\text { Nethyl clupano } \\
\text { conste }\end{array}$ \\
\hline 1 & 0.2 & 0.08 & & 0.12 & & & \\
\hline 2 & 0.7 & 0.32 & & 0.38 & & & \\
\hline 3 & 1.0 & 0.22 & 0.11 & 0.67 & & & \\
\hline 4 & 1.7 & 0.11 & 0.33 & 1.26 & & & \\
\hline 5 & 3.7 & & 0.44 & 1.67 & 1.59 & & \\
\hline 6 & 13.2 & & & & 10.56 & 2.64 & \\
\hline 7 & 8.1 & & & & 6.48 & 1.62 & \\
\hline 8 & 4.2 & & & & 3.36 & 0.84 & \\
\hline 9 & 1.2 & & & & & 1.2 & \\
\hline 10 & 0.9 & & & & & 0.9 & \\
\hline 11 & 1.9 & & & & & 1.9 & \\
\hline 12 & 4.3 & & & & & 0.86 & 3.44 \\
\hline 13 & $4.2^{2}$ & & & & & & 3.2 \\
\hline ronar & 45.3 & 0.73 & 0.88 & 4.10 & 21.99 & 20.26 & 2.34 \\
\hline
\end{tabular}

The $4.2 \mathrm{~g}$. present is $0.3 \mathrm{~g}$. of wnsaponiflable resicue and $3.9 \mathrm{~g}$. of of resitue composed of hichly unsaturated aclds 
The "11quid" latty aeld fraction obtalned by the lesd seltether method 1. 7.0 per cent of the totel maice o11. On eonvertIng the values for the variou wothyl esters, as shom in Feble III. the folloving pereentages of aclde are obtained:

\section{F⿻上丨 IV}

Percentage Compostion of "Lquid" Jatty Meld Fraction (Calculsted fron Data in Fables II and III)

\begin{tabular}{|c|c|}
\hline Ilane of Meid & Pereentage \\
\hline Nyrietie & 1.25 \\
\hline Palnitie & 1.39 \\
\hline Fersadecenoic & 6.43 \\
\hline Olele & 34.48 \\
\hline Innolele & 16.00 \\
\hline Arachidonic and Clupanodonte & 10.98 \\
\hline Ungepont fiable Resiche & 0.57 \\
\hline TOFA工 & 7.00 \\
\hline
\end{tabular}


The date in Fable $V$ was obtalned by sractlonating the nethy 2 ester. Irov the "molld" adis.

\section{Trex $\mathbf{v}$}

Date Obtained Irom Distiliation at $1 \mathrm{~mm}$. of 20.0 Grans

of Nethyl Inters of "Solid" Melds.

"Sol14" solds Produced by Ioad-Selt-mther Iothod.

\begin{tabular}{|c|c|c|c|c|c|}
\hline Fraet1on & $\begin{array}{c}\text { Termerature } \\
\left({ }^{\circ} \mathrm{c} .\right)\end{array}$ & $\left|\begin{array}{r}\text { Welght of } \\
\text { ryaction } \\
(1 \mathrm{n}, \mathrm{B})\end{array}\right|$ & $\mathbf{n}_{D}^{25}$ & $\begin{array}{l}\text { Saponsel- } \\
\text { cation } \\
\text { zquitaien t }\end{array}$ & $\begin{array}{l}\text { Iodine } \\
\text { Value } \\
\text { (Feme) }\end{array}$ \\
\hline 1 & $121-124$ & 0.2 & 1.4358 & - & 3.2 \\
\hline 2 & $125-128$ & 0.3 & 1.4365 & - & 0.7 \\
\hline 3 & $129-139$ & 4.2 & Solld & 270.9 & 1.7 \\
\hline 4 & $140-243$ & 4.5 & So21a & 275.3 & 0.3 \\
\hline 5 & 144 & 3.3 & Sol1d & 280.2 & 0.0 \\
\hline 6 & $145-250$ & 1.2 & 1.4398 & $277 \cdot 0$ & 6.5 \\
\hline 7 & $150-154$ & 1.0 & Sol1a & 281.9 & 11.7 \\
\hline 8 & $154-264$ & 3.9 & Sol1d & 299.5 & 8.4 \\
\hline 9 & Residuc & 0.7 & Soz1d & 292.5 & 9.3 \\
\hline
\end{tabular}


Iron the saponiflestion oquivalents, refractive indices, and Iodine Valves shom in Fable $\mathrm{V}$ the breatudoun of the various fractions gofren in table VI has been caleulated.

\section{TATRW VI}

Ister Conposition of Irsctions Obtalned Irom Distilletien at $1 \mathrm{~m}$. of 20.3 grams of Nothy1 Imtera of "Eol1a" Molde. "SoLda" Melds Produced by Lead-Selt-withor liethod

\begin{tabular}{|c|c|c|c|c|c|c|}
\hline \multirow[b]{2}{*}{ Sarplo } & \multirow{2}{*}{$\begin{array}{l}\text { Welght of } \\
\text { Jraction } \\
\text { (1a G.) }\end{array}$} & \multirow[b]{2}{*}{$\begin{array}{l}\text { Tothol } \\
\text { sordst- } \\
\text { ate } \\
\end{array}$} & \multirow[b]{2}{*}{$\begin{array}{c}\text { Tethol } \\
\text { hexadeoe- } \\
\text { noste }\end{array}$} & \multirow[b]{2}{*}{$\begin{array}{l}\text { Vothy I } \\
\text { painit- } \\
\text { ste }\end{array}$} & \multirow[b]{2}{*}{$\begin{array}{l}\text { Iethy } \\
\text { oleato }\end{array}$} & \multirow[b]{2}{*}{$\begin{array}{l}\text { Hothyl } 1 \\
\text { stearate }\end{array}$} \\
\hline & & & & & & \\
\hline 1 & 0.2 & 0.194 & 0.006 & & & \\
\hline 2 & 0.3 & 0.298 & 0.002 & & & \\
\hline 3 & 4.2 & & 0.073 & 4.027 & & \\
\hline 4 & 4.5 & & & 3.645 & & 0.855 \\
\hline 5 & 3.3 & & & 2.079 & & 1.221 \\
\hline 6 & 1.2 & & & 0.972 & 0.091 & 0.137 \\
\hline 7 & 1.0 & & & 0.575 & 0.063 & 0.367 \\
\hline 8 & 3.9 & & & & 0.390 & 3.510 \\
\hline 2 & 0.2 & & & 0.140 & 0.061 & 0.498 \\
\hline TOTAIS & 19.2 & 0.492 & 0.081 & 21.438 & 0.605 & 6.589 \\
\hline
\end{tabular}


The "bolla" fatty aclds fraction obtalned by the leed-saltethor method. Is 24.4 per cent of the total snaico o11. On convertIns the values for the rartous nethyl esters, as whon in $2 a b 10$ VI. Into the percentages of the orl ginal snake oll the folloulng rewults are obtalned:

\section{PABR교 VII}

Perceatagen of Fatty Molde in the "Solla" Fraction

(Calculated fron Fable VI)

\begin{tabular}{|c|c|}
\hline Irame of Acid & Percentage \\
\hline Wrietie & 0.62 \\
\hline Fexadecenoto & 0.20 \\
\hline Palnitic & 14.54 \\
\hline 01ele & 0.77 \\
\hline Stearle & 8.37 \\
\hline Torns. & 24.40 \\
\hline
\end{tabular}

When the acid pereentages fron the "Iiquid" and "solia" latty aeids frections vere added the date fiven on the folloving page in 2able VII were obtalned. 


\section{TABr: VIII}

Percentage of Fatty Mclas in Combined "MLqua" and "Solla" Frations of Voccasin Snaice 011.

Fractions Obtalned by the Iead-Salt-5ither Nethod

\begin{tabular}{|c|c|}
\hline Flame of scta & Percentage \\
\hline Horietse & 1.77 \\
\hline Palntic & 15.93 \\
\hline Stearle & 8.37 \\
\hline Fexadecenole & 6.53 \\
\hline Olele & 35.25 \\
\hline Inolate & 16.00 \\
\hline Arachitonte and clupenodonte & 10.97 \\
\hline $\operatorname{Tos} A$ & 94.82 \\
\hline
\end{tabular}

Fable III is besed upon the dist1Ilation date shorm In Fables II to FII, Inclueive.

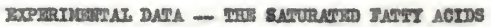

The data obtalned Iron the frectional distillation of the "solid"

Irection of the noccasin enelce oll in fiven in the section on distilistion.

After soparation of the "solid" Iatty seids fron the "I1quid"

Patty acids by use of the lead-ialt-ether procedure, it vas found that

the Average Nolecular Velght of the "aolla" fatty acid Iraction is

264.2, Whle that of the "Ilquid" fatty ac1d Iraction is 290. 
Before exaulning the data obtalnod Irom the lead-aalt-ether seperation, the semple we teated for possible oxddation of the wnפaturated sclds. The follovins data were obtained:

Iodine thuber (Hams), Origlnal Hoecasin Snaks 011...107.1

Iocise Itumber (Hanus), "Bolid" Jreotion........... 9.7

Iodine Mumber (Hama), "Llquid" Traction............145.6

The conbined roalne Values of the "IIquia" and "volld" fatty actd Iractions secount for 99.2 por eent of the masturation of the arifinal make oll.

Work with the "solid" acld fraction showed that It contelned a high percentage of palaltie and stearie acids. Therefore, it was desiralle to have a frection whi on containod only pelaltie and stear16 aclds. Thls paypose vas achleved by vee of a solution of methanol and vater of a speelfle gravity of 0.911 at $0^{\circ} \mathrm{C}$. The solution van saturated wth peinitic and stearle acid, and to this saturated

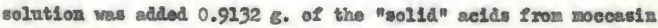
snolse 011. Lfter the mixhure had revained overmight in a Frigldatre, the preelpitate wa weighed; and a total of 0.8234 f. of fatty solds ves obtalned. Undar the conditions of the experinent, oniy a mixture of palnitio and stearle aclds showld have precipitated.

The ereesine point of the prealpltate vas deternined to be $54^{\circ} \mathrm{O}$. According to Relston96, the Ireezing polnt of a binury mixture of palntic and otearle acids in vilch the mole frection of palaitle is 0.7 and the mole Iraction of stearie is $0.3 .1854^{\circ} \mathrm{C}$. The average 
nolecular velght of Rulston's mixture mas 265.6, willo the sctual everage nolecular welght of the precipitate was 265.2.

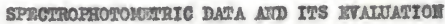

The spectrophotometer waed was a Beclanen Nodel DO with a 10.2501 U1traviolet Mocessory Set attached. The witrarlolet accesory set provlded the necesøaxy equipment for maling meeauremente in the ware length reglon of 350 to 220 atilimierons.

The above axparatus ves tested and runs were made to standardize and chocik it for efficlency of gperation. For the stendard methods of operation the reader is reforred to the various Beclanen Bulletint.

The procedure used in this phase of the reseerch is one which was

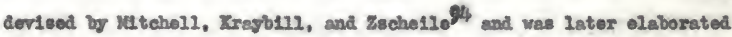
upon by Boadle and Ireybi1195. They report that it is poseible to doteralne the pereontege of IInoleic, Iinolenie, and arachidonie acids by isovertaing the double bonds into conjugated positions in an alkoline solution of ethylene glyeol.

The method used was as follows:

Batween 0.1 and $0.2 \mathrm{~g}$. of noccesin walioe ofl wes eccurately veighed and pleced in the tyge of amall rial used for Iodine Mlumber detemination. In a $15 \times 2.5 \mathrm{en} .(6 \times 1 \mathrm{in}$. $)$ test tube vere placed $10 \mathrm{ml}$. of alkaline glyeol reagent. The test tube was corered loosely with a class exp and was loept imnorsed at a constent depth in an oll beth at $180^{\circ} \mathrm{C}$. When the temperature of the reagent in the test trabe 
had reached $180^{\circ} \mathrm{C}$. the $\nabla$ ial contelnine the moceasin analce oil was arogped Into the tube. The tost tube vas sviried three tines at oneminate intervals to mlx the fat with the glyool solutien.

After 25 minates the tube was renovd from the bath and vas cooled repidiy under the tep. The contents of the tube were traneferred quant1tatively to a $250 \mathrm{ml}$. volumetric Rasic. Fithanol vel nsed to vash out the tube, and the voluas was alluted vith 99 per cent ethenal.

The aamples tood in a refrlgerator overnight. The meterials remored frow the tube in the hot allonll solution hed precipitated. The solution in the volunetrie ilask was brought to roon terperatrure, and a portlon of 1 was filtered. Proper aslution for absorption mesuremonts vere sede wth 99 per cent ethanol.

It we necessery to carry a blank solution of allaline glyeol throvghert the wole procedure, Ineluding dilution, for use in the solvent cell.

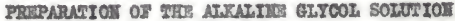

Potastiw hyiroxdde (7.5 5. asmaylng 85 per cent) was added to $100 \mathrm{ml}$. of ethylene plyeol, resulting in a 1.3 E potassiva hyiroxide solution. While preparing the reagent, the elyeol solution wae bollod

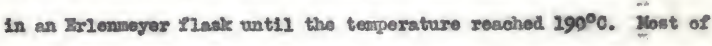
the vater was removed by boiling, so that it was possible to malntaln a tenperature of $180^{\circ} \mathrm{O}$. While the sabrie was being heated. 
The formula used to dotermine speclete alphs is:

Specisic alphs $=\frac{\log _{10} x_{0} / x}{e^{2}}$

Alphs = Abaorption coefileient

$I_{0}=$ intengity of radiation trensmitted by the solvent

$I=$ intensity of redistion tranand ted by the solution

e = concentration of solute in grams per $1000 \mathrm{wl}$.

$I=$ length in centinoters of colution throuch wich the redistion passes.

Fable IX five the standard values reported is Beadie and

Krayb11195 for the ceternination of fatty acid alxtures contalaing 1inolete, Iinolente, and arechtdonte selds:

\section{WMath IX}

Reference Values for Use in Spectrophotonetrle Analys

\begin{tabular}{|c|c|c|c|c|}
\hline \multirow{2}{*}{$\begin{array}{c}\text { Isonerlaced fatty acld } \\
\text { soep }\end{array}$} & \multicolumn{4}{|c|}{ Specifie Absorption Coefficlent } \\
\hline & $2340 \&$ & $2680 \AA$ & 3010 \& & $3160 \AA$ \\
\hline Arachidonte & 59.3 & 53.4 & 25.8 & 22.6 \\
\hline Innolende & 60.9 & 53.2 & & \\
\hline Inolele & 86.0 & & & \\
\hline
\end{tabular}


In order to eraluate the apeetrophotonetrle dats Irom the isomex-

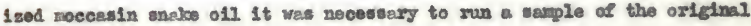
011. After investigation 1 was found. that diethyl ether is a good solvent. In spectrophotometric work it 18 necossary to heve a solvent which does not absorb ultrarlolet 11 ght so that all absorption whom vill be that of the compound to be exculnod. The orlginal eoneentram t1on wa 10 grans of moccasin enalce oll to which was addod enorgh diothy 1 ether to make a total volume of $100 \mathrm{ml}$. Whis gives a 10 per cent solution of mocoesin anaks oll.

\section{고ำ $x$}

Speotrophotonatrle Data on Pure, Cold-presed Nocessin Snake 011

\begin{tabular}{|c|c|c|c|c|c|}
\hline $\begin{array}{l}\text { Vave Irength } \\
\text { In } \\
\text { Angstrons }\end{array}$ & Alphe & $\operatorname{Iog} \frac{I_{0}}{I}$ & $\begin{array}{r}\text { S11t } \\
\text { Vuath }\end{array}$ & $\begin{array}{l}\text { Concen- } \\
\text { tration }\end{array}$ & $\begin{array}{l}\text { Iog Specifle } \\
\text { Dxtinotion } \\
\text { coefletent }\end{array}$ \\
\hline 3500 & 0.00167 & 0.167 & $0.8 \mathrm{man}$. & $c^{2}$ & -2.7773 \\
\hline 3400 & 0.00227 & 0.227 & $0.8 \mathrm{~ms}$. & C & -2.6640 \\
\hline 3300 & 0.00326 & 0.326 & $0.8 \mathrm{men}$. & C & -2.4864 \\
\hline 3200 & 0.00534 & 0.534 & 0.8 =. & c & -2.2733 \\
\hline 3180 & 0.00586 & 0.586 & $0.8=$ & 0 & -2.2321 \\
\hline 3150 & 0.00614 & 0.614 & $0.8 \mathrm{~m}$. & 0 & -2.2118 \\
\hline 3230 & 0.00610 & 0.610 & $0.8=$ & c & -2.2147 \\
\hline 3120 & 0.00605 & 0.605 & 0.8 س. & 6 & -2.2147 \\
\hline
\end{tabular}

In the concentretion colvun, 0 indicates 10 per cent moccasin malce olldethyl ethex solution. 
TABRSE X (Contimad)

Spectrophotometrie Dete on Pure, Cold-preseed Hocessin Snelce 012

\begin{tabular}{|c|c|c|c|c|c|}
\hline $\begin{array}{l}\text { Wave Jengthy } \\
\text { in } \\
\text { Ance troms }\end{array}$ & Alpha & $\log \frac{I_{0}}{I}$ & $\begin{array}{l}\text { sust } \\
\text { videth }\end{array}$ & $\begin{array}{l}\text { Concen- } \\
\text { tration }\end{array}$ & $\begin{array}{l}\text { Iog Specifle } \\
\text { zatinotion } \\
\text { eoeffielent } \\
\end{array}$ \\
\hline 3100 & 0.00617 & 0.617 & $0.8 \mathrm{ma}$ & $c$ & -2.2097 \\
\hline 3050 & 0.00782 & 0.208 & $0.8 \mathrm{~mm}$ & $0 / 4$ & -2.1040 \\
\hline 3000 & 0.01050 & 0.262 & 0.8 = & $0 / 4$ & -1.9798 \\
\hline 2950 & 0,01328 & 0.332 & $0.8 \mathrm{man}$ & $c / 4$ & -1.9721 \\
\hline 2900 & 0.02005 & 0.501 & $0.8 \mathrm{~m}$ & $0 / 4$ & -2.6990 \\
\hline 2850 & 0.03668 & 0.917 & $0.8 \mathrm{man}$. & $c / 4$ & -1.4318 \\
\hline 2800 & 0.0512 & 0.321 & $0.8 \mathrm{~mm}$. & $0 / 16$ & -1.2907 \\
\hline 2750 & 0.0547 & 0.342 & 0.8 m. & $c / 16$ & -1.2620 \\
\hline 2700 & 0.0685 & 0.427 & $0.8 \mathrm{~mm}$. & $0 / 16$ & -1.1643 \\
\hline 2680 & $0.077^{4}$ & 0.121 & $0.8 \mathrm{am}$. & $0 / 16$ & -1.1113 \\
\hline 2650 & 0.0665 & 0.104 & $0.8 \mathrm{~mm}$. & $c / a$ & -1.1772 \\
\hline 2600 & 0.0742 & 0.117 & $0.8 \mathrm{~mm}$. & $c / 64$ & -2.13 \\
\hline 2550 & 0.2424 & 0.221 & $0.8 \mathrm{~mm}$. & $c / 64$ & -0.85 \\
\hline 2500 & 0.4147 & 0,167 & $0.8 \mathrm{~m}$. & $c / 64$ & -0.40 \\
\hline 2450 & 0.888 & 0.347 & $0.8 \mathrm{~km}$. & $c / 256$ & -0.05 \\
\hline 2400 & 1.270 & 0.494 & $0.8 \mathrm{man}$ & $c / 256$ & +0.10 \\
\hline 2350 & 1.515 & 0.592 & $0.8 \mathrm{~m}$ & $c / 256$ & +0.18 \\
\hline 2300 & 1.567 & 0.612 & $1.0 \mathrm{ma}$ & $c / 256$ & +0.20 \\
\hline 2250 & 3.472 & 0.575 & $1.5 \mathrm{man}$ & $0 / 256$ & +0.17 \\
\hline 2200 & 1.510 & 0.590 & $2.0=$ & $c / 256$ & +0.179 \\
\hline
\end{tabular}


In order to graph the data glven in Table $x$ it is nooeseary to vee the Iog Specifle Ixtinction Coeffieient. This naise it possiblo to plece all of the graph on one curre. The Iog Specifle Iutinetion Coefflelent is obtained by telding the Iog to base 10 of the Mpha valve in Fable $x$. Por this sraph see F1Eure 1. 


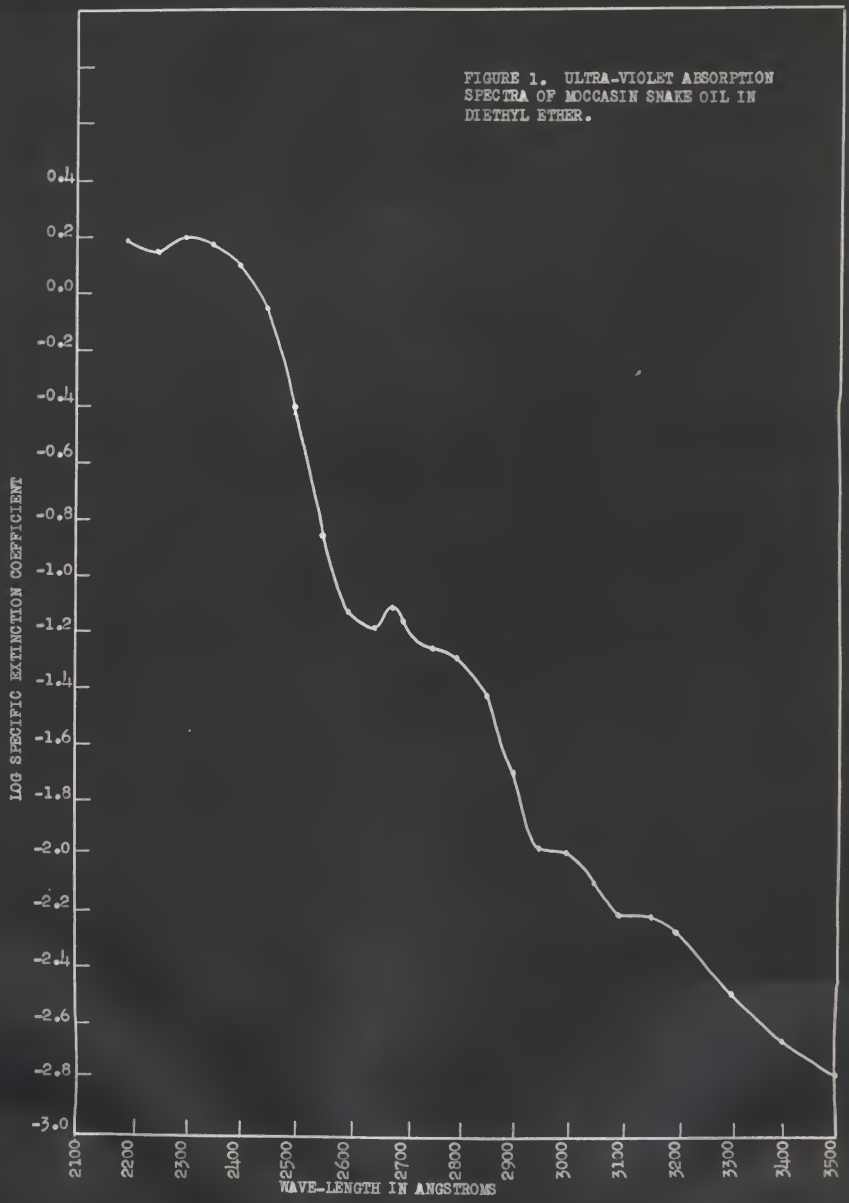




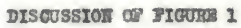

The absorption at 2340 Angstroms is cerased by the diene confegation. The alphe value is 1.525. If 100 per cent confrgated linolele acld given an alphe of 86.0 , if 100 per cent conjugated 12 nolenis acid Gives an alpha of 60.9 , and if 200 per cent confugated arach1donic acid gives an alphe of 59.3, then 1t 18 ponsible to osloulato the amount of confugation present fros the resurts found. If all the ebsorption at 2340 Angstrom is sssumed to be 1ineoleie, then there is present in the oridnel moceasin snske o11 1.77 per cent of a confugsted I1noleic acld. Fy the sase prosedure It we found that the pereentage of eonjugated trienes in the original moccasin ancica ofl was 0.15 , and the percentage of confugated tetreeno present in the ortetinal moccesin snake ofi was 0.04 . The triene absorption show at the 2680 Angetrom wave length. The tetraene absorptlon shows at the 3010 Angstroms and the 3160 Angstrams wave length. 


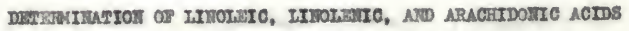

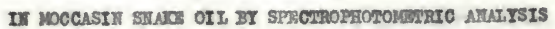

The analo ofl used in this determinetion was leomerized in an alkaline glyeol solution in accordance with the method of vitche11,

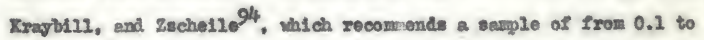
0.2 gxen. A sample of moccastn snalse 011, $0.1355 \mathrm{gxan}$, was nede up to a volume of $100 \mathrm{ml}$. with 99 per cent ethenol, according to the proeedure whieh was cescribed in cotail in the preceding section. This solution of 0.1355 rase of snalce ofl per $100 \mathrm{ml}$. Is represented In the table by $C$ in the concentration colum.

A Beclonen spectrophotometer was used, and readings were recorded at intervals of 10 Anstrons throughout the range from 3500 to 2170 Angatrons. The result are reported in Table $\mathrm{II}$. Since the $10 \mathrm{~g}$ alpha 1s the sane as the $10 \mathrm{~g}$ Speclfic satinetion Coefficient, the log alpha for each wave leagth was not tabulated.

\section{Tara $\mathrm{xT}$}

Dotemination of Inolele, Ifnolate, and Arechtionie delas in Hoceamin Snake 012 by Spectrophotonotrle Analyeis

\begin{tabular}{|c|c|c|c|c|c|}
\hline $\begin{array}{l}\text { Weve Iength } \\
\text { in } \\
\text { Anestrons }\end{array}$ & Alpha & $\log \frac{I_{0}}{I}$ & $\begin{array}{l}\text { silt } \\
\text { Width }\end{array}$ & $\begin{array}{l}\text { Concers } \\
\text { tration }\end{array}$ & $\begin{array}{l}\text { Iog Spocisic } \\
\text { Jutinction } \\
\text { Coofficient }\end{array}$ \\
\hline 3500 & 0.80 & 0.108 & $0.8 \mathrm{~mm}$. & $c / 10$ & -0.0969 \\
\hline 3490 & 0.84 & 0.124 & $0.8 \mathrm{~mm}$. & $0 / 10$ & -0.0757 \\
\hline 3480 & 0.86 & 0.117 & $0.8 \mathrm{man}$. & $0 / 20$ & -0.0655 \\
\hline
\end{tabular}


TABIS XI (Continued)

\begin{tabular}{|c|c|c|c|c|c|}
\hline $\begin{array}{l}\text { Vare Iength } \\
\text { in } \\
\text { Ancetrons }\end{array}$ & Alphe & $\operatorname{Iog} \frac{I_{0}}{I}$ & $\begin{array}{l}\text { S11t } \\
\text { Width }\end{array}$ & $\begin{array}{l}\text { Concen- } \\
\text { tration }\end{array}$ & $\begin{array}{l}\text { Iog Specifle } \\
\text { Ixtinction } \\
\text { Coepiclent }\end{array}$ \\
\hline 3470 & 0.86 & 0.117 & 0.8 2us. & $0 / 10$ & -0.0655 \\
\hline 3160 & 0.84 & 0.114 & $0.8 \mathrm{~m}$ & $6 / 10$ & -0.0755 \\
\hline 3450 & 0.80 & 0.108 & $0.8 \mathrm{~mm}$. & $0 / 10$ & -0.0969 \\
\hline 3440 & 0.75 & 0.102 & 0.8 want. & $0 / 20$ & -0.1249 \\
\hline 3430 & 0.70 & 0.094 & $0.8 \mathrm{~m}$. & $0 / 10$ & -0.1549 \\
\hline 3420 & 0.64 & 0.087 & $0.8 \mathrm{~ms}$. & $0 / 10$ & -0.1938 \\
\hline 3420 & 0.61 & 0.083 & 0.8 เมืเ. & $c / 20$ & -0.2147 \\
\hline 3400 & 0.61 & 0.082 & $0.8 \mathrm{xw}$. & $c / 10$ & $-0,2147$ \\
\hline 3390 & 0.61 & 0.083 & 0.8 wan. & $c / 20$ & -0.2247 \\
\hline 3380 & 0.64 & 0.087 & 0.8 또. & $c / 20$ & -0.1938 \\
\hline 3370 & 0.68 & 0.092 & $0.8 \mathrm{zm}$ & $c / 10$ & -0.1675 \\
\hline 3360 & 0.73 & 0.099 & $0.8 \mathrm{man}$ & c/20 & $-0.136 y$ \\
\hline 3350 & 0.79 & 0.107 & $0.8 \mathrm{man.}$ & $0 / 10$ & -0.1024 \\
\hline 3340 & 0.86 & 0.116 & 0.8 25. & $c / 20$ & -0.0655 \\
\hline 3330 & 0.93 & 0.126 & $0.8 \mathrm{~s}$ & $6 / 20$ & -0.0325 \\
\hline 3320 & 2.02 & 0.138 & 0.8 핌. & c/20 & -0.0086 \\
\hline 3320 & 1.04 & $0.2 / 11$ & 0.8 nis. & $0 / 10$ & -0.0170 \\
\hline 3300 & 1.06 & 0.144 & $0.8 \mathrm{men.}$ & $0 / 20$ & +0.0253 \\
\hline 3290 & 1.08 & 0.247 & $0.8 \mathrm{mat}$ & $0 / 20$ & 0.0334 \\
\hline 3280 & 2.10 & 0.149 & $0.8 \mathrm{~mm}$. & $0 / 20$ & +0.0424 \\
\hline 3270 & 1.11 & 0.250 & $0.8 \mathrm{rms}$ & $0 / 10$ & -0.0453 \\
\hline
\end{tabular}


TARTh $\times$ (Contimad)

\begin{tabular}{|c|c|c|c|c|c|}
\hline $\begin{array}{l}\text { Werve Iongth } \\
\text { In } \\
\text { Angetrom }\end{array}$ & Alphe & $\operatorname{Iog} \frac{I_{0}}{I}$ & $\begin{array}{l}\text { s11t } \\
\text { ind th }\end{array}$ & $\begin{array}{l}\text { Concen- } \\
\text { tration }\end{array}$ & $\begin{array}{l}\text { Iog Specisio } \\
\text { Lxtinction } \\
\text { Coefficient }\end{array}$ \\
\hline 3260 & 1.22 & 0.252 & 028 피. & $0 / 10$ & +0.0492 \\
\hline 3250 & 1.26 & 0.257 & $0.8 \mathrm{mans}$ & $c / 10$ & +0.0645 \\
\hline 3240 & 1.24 & 0.168 & $0.8 \mathrm{z}$ & $0 / 10$ & +0.0934 \\
\hline 3230 & 1.34 & 0.282 & 0.8 sal. & $6 / 10$ & +0.1272 \\
\hline 3220 & 2.50 & 0.203 & 0.8 aa. & $c / 20$ & -0.1761 \\
\hline 3210 & 1.70 & 0.232 & $0.8 \mathrm{~mm}$. & $0 / 10$ & +0.2304 \\
\hline 3200 & 1.92 & 0.260 & $0.8 \mathrm{~mm}$ & $0 / 10$ & +0.2833 \\
\hline 3190 & 2.15 & 0.292 & $0.8 \mathrm{~mm}$. & $c / 10$ & +0.3324 \\
\hline 3180 & 2.38 & 0.322 & $0.8 \mathrm{zm}$. & $c / 10$ & +0.3766 \\
\hline 3170 & 2.53 & 0.343 & $0.8 \mathrm{~m}$. & $c / 20$ & +0.4032 \\
\hline 3160 & 2,61 & 0.354 & 0.8 vin. & c/10 & +0.4166 \\
\hline 3150 & 2.60 & 0.353 & $0.8 \mathrm{ma}$. & $6 / 10$ & +0.4150 \\
\hline 3140 & 2.52 & 0.342 & 0.8 피. & $c / 10$ & +0.4014 \\
\hline 3230 & 2.39 & 0.323 & $0.8 \mathrm{~mm}$ & $c / 10$ & +0.3784 \\
\hline $3220^{\circ}$ & 2.23 & 0.302 & 0.8 = & $c / 20$ & +0.3783 \\
\hline 3210 & 2.08 & 0.282 & $0.8 \mathrm{~ms}$. & $c / 10$ & +0.3282 \\
\hline 3200 & 1.99 & 0.269 & $0.8 \mathrm{~m}$. & c/10 & +0.2989 \\
\hline 3090 & 1.94 & 0.263 & $0.8 \mathrm{sm}$ & $c / 10$ & -0.2878 \\
\hline 3080 & 1.99 & 0.268 & 0.8 xas. & $c / 10$ & +0.2989 \\
\hline 3070 & 2.08 & 0.282 & 0.8 มाष्ट. & $c / 10$ & +0.3182 \\
\hline 3060 & 2.23 & 0.302 & $0.8 \mathrm{wm.}$ & $c / 10$ & -0.3483 \\
\hline
\end{tabular}


sAars $x a$ (Cont1nued)

\begin{tabular}{|c|c|c|c|c|c|}
\hline $\begin{array}{l}\text { Wave Length } \\
\text { in } \\
\text { Angetrons }\end{array}$ & Alphe & $\log \frac{I_{0}}{I}$ & $\begin{array}{l}\text { s11t } \\
\text { vidth }\end{array}$ & $\begin{array}{l}\text { Concen- } \\
\text { tration }\end{array}$ & $\begin{array}{l}\text { Log Specilie } \\
\text { Jutinction } \\
\text { Coeffletent }\end{array}$ \\
\hline 3050 & 2.42 & 0.326 & 0.8 ma. & $0 / 10$ & +0.3820 \\
\hline 3040 & 2.59 & 0.352 & 0.8 шा. & $0 / 10$ & -0.4233 \\
\hline 3030 & 2.74 & 0.372 & $0.8 \mathrm{man}$. & $6 / 20$ & +0.4378 \\
\hline 3020 & 2.86 & 0.388 & 0.8 =m. & $6 / 20$ & +0.4564 \\
\hline 3010 & 2.90 & 0.393 & $0.8 \mathrm{man}$. & $0 / 10$ & $+0.462 \%$ \\
\hline 3000 & 2.85 & 0.386 & $0.8 \mathrm{mas}$ & $6 / 10$ & -0.4548 \\
\hline 2990 & 2.73 & 0.370 & $0.8 \mathrm{x}$ x内ा. & $6 / 10$ & +0.4362 \\
\hline 2980 & 2.60 & 0.353 & $0.8 \mathrm{mat}$ & $c / 10$ & +0.4250 \\
\hline 2970 & 2.47 & 0.334 & $0.8 \mathrm{man}$ & $c / 10$ & +0.3927 \\
\hline 2960 & 2.38 & 0.322 & $0.8 \mathrm{ma}$. & c/10 & -0.3766 \\
\hline 2950 & 2.35 & 0.318 & $0.8 \mathrm{men}$. & e/10 & +0.3711 \\
\hline 2940 & 2.42 & 0.328 & 0.8 표. & c/10 & -0.3838 \\
\hline 2930 & 2.56 & 0.347 & $0.8 \mathrm{gms}$. & $0 / 10$ & -0.4082 \\
\hline 2920 & 2.77 & 0.376 & $0.8 \mathrm{zm.}$ & c/10 & +0.4425 \\
\hline 2910 & 3.06 & 0.415 & 0.8 프. & $c / 20$ & -0.4857 \\
\hline 2900 & 3.36 & 0.455 & 0.8 피. & $c / 10$ & +0.5263 \\
\hline 2890 & 3.74 & 0.507 & $0.8 \mathrm{tm}$ & $c / 10$ & +0.5729 \\
\hline 2880 & 4.15 & 0.563 & 0.8 폼. & $0 / 10$ & -0.6180 \\
\hline 2870 & 4.59 & 0.622 & $0.8 \mathrm{~mm}$ & $c / 20$ & +0.6618 \\
\hline 2860 & 4.00 & 0.677 & $0.8 \mathrm{m.}$ & $0 / 20$ & +0.6990 \\
\hline 2850 & 5.44 & 0.737 & 0.8 гін. & $0 / 10$ & 0.7356 \\
\hline
\end{tabular}


TABDI XI (Contimad)

\begin{tabular}{|c|c|c|c|c|c|}
\hline $\begin{array}{c}\text { Weve Leneth } \\
\text { In } \\
\text { Anestroms }\end{array}$ & Alphe & $\log \frac{I_{0}}{I}$ & $\begin{array}{l}\text { S11t } \\
\text { W1ath }\end{array}$ & $\begin{array}{l}\text { Concen- } \\
\text { tration }\end{array}$ & $\begin{array}{l}\text { Log Speolfie } \\
\text { Intinetion } \\
\text { Coefflefent }\end{array}$ \\
\hline 2840 & 5.90 & 0.800 & 0.8 జు. & $0 / 10$ & +0.709 \\
\hline 2830 & 6.32 & 0.856 & $0.8 \mathrm{~m}$. & $0 / 10$ & +0.8007 \\
\hline 2820 & 6.61 & 0.896 & $0.8 \mathrm{~mm}$. & $c / 20$ & +0.8206 \\
\hline 2810 & 6.94 & 0.940 & $0.8 \mathrm{ma.}$ & $0 / 20$ & $\infty .8424$ \\
\hline 2800 & 7.03 & 0.952 & $0.8 \mathrm{~m}$ & $0 / 10$ & .0. 84po \\
\hline 2790 & 7.03 & 0.952 & $0.8 \mathrm{zm}$. & $0 / 10$ & +0.8470 \\
\hline 2780 & 7.00 & 0.948 & $0.8 \mathrm{~mm}$ & $0 / 10$ & $\$ 0.8453$ \\
\hline 2770 & 6.96 & 0.943 & $0.8 \mathrm{~mm}$ & $c / 20$ & +0.8426 \\
\hline 2760 & 6.89 & 0.933 & $0.8 \mathrm{~mm}$ & $0 / 10$ & +0.8382 \\
\hline 2750 & 6.96 & 0.943 & $0.8 \mathrm{~mm}$. & $0 / 10$ & -0.8426 \\
\hline 2740 & 7.08 & 0.960 & $0.8=$ & $0 / 10$ & +0.8500 \\
\hline 2730 & 7.36 & 0.997 & $0.8=$ & $c / 10$ & 40.8659 \\
\hline 2720 & 7.65 & 1.037 & $0.8 \mathrm{~mm}$. & $0 / 10$ & +0.8837 \\
\hline 2720 & 7.88 & 1.068 & 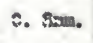 & $c / 10$ & -0.8955 \\
\hline 2700 & 8.34 & 1.130 & $0.8 \mathrm{~mm}$ & $c / 10$ & -0.9212 \\
\hline 2690 & 8.31 & 2.126 & $0.8=$ & $0 / 10$ & +0.9196 \\
\hline 2680 & 8.18 & 1.108 & $0.8=$ & $0 / 10$ & +0.9128 \\
\hline 2670 & 8.17 & 1.107 & $0.8 \mathrm{sm}$. & $c / 10$ & +0.9122 \\
\hline 2660 & 7.55 & 1.023 & $0.8 \mathrm{mas}$ & $0 / 10$ & +0.8779 \\
\hline 2650 & 7.28 & 0.986 & $0.8 \mathrm{man}$. & $0 / 10$ & $\leftarrow 0.8622$ \\
\hline 2640 & 6.92 & 0.938 & 0.8 피. & $c / 10$ & +0.8401 \\
\hline 2630 & 6.73 & 0.912 & $0.8 \mathrm{~mm}$. & $0 / 10$ & +0.8280 \\
\hline
\end{tabular}


TASTIS XI (Contimod)

\begin{tabular}{|c|c|c|c|c|c|}
\hline $\begin{array}{c}\text { Weve Iensth } \\
\text { in } \\
\text { Ingetrons }\end{array}$ & Alpha & $\operatorname{Iog} \frac{I_{0}}{I}$ & $\begin{array}{l}\text { 511t } \\
\text { vidth }\end{array}$ & $\begin{array}{l}\text { Concen- } \\
\text { tration }\end{array}$ & $\begin{array}{l}\text { Iog Speciflo } \\
\text { Taxtinetion } \\
\text { Coeffleiont }\end{array}$ \\
\hline 2620 & 6.60 & 0.895 & 0.8 삐. & $c / 10$ & +0.8195 \\
\hline 2610 & 6.61 & 0.896 & $0.8 \mathrm{~mm}$. & $c / 10$ & +0.8202 \\
\hline 2600 & 6.64 & 0.900 & $0.8 \mathrm{~mm}$. & $0 / 10$ & +0.8222 \\
\hline 2590 & 6.60 & 0.895 & $0.8 \mathrm{~mm}$ & $0 / 10$ & +0.2195 \\
\hline 2580 & 6.57 & 0.890 & $0.8 \mathrm{~mm}$. & $0 / 10$ & +0.8176 \\
\hline 2570 & 6.46 & 0.875 & $0.8 \mathrm{man}$. & $0 / 10$ & +0.8102 \\
\hline 2560 & 6.37 & 0.863 & $0.8=$ & $0 / 10$ & +0.8041 \\
\hline 2550 & 6.31 & 0.855 & $0.8=$ & $c / 10$ & +0.8000 \\
\hline 2540 & 6.35 & 0.861 & $0.8 \mathrm{mat}$. & $0 / 10$ & +0.8028 \\
\hline 2530 & 6.57 & 0.892 & $0.8 \mathrm{~mm}$. & $0 / 10$ & +0.8176 \\
\hline 2520 & 7.02 & 0.950 & $0.8 \mathrm{man}$. & $c / 10$ & +0.8463 \\
\hline 2510 & 7.64 & 1.030 & $0.8 \mathrm{~mm}$. & $c / 10$ & +0.8831 \\
\hline 2500 & 8.18 & 1.116 & $0.8 \mathrm{~mm}$. & $c / 10$ & +0.9128 \\
\hline 2490 & 9.74 & 0.132 & $0.8 \mathrm{ma}$ & $c / 200$ & +0.9886 \\
\hline $2 / 480$ & 10.63 & 0.144 & $0.8 \mathrm{~mm}$ & c/100 & +1.0265 \\
\hline 2470 & 11.66 & 0.158 & $0.8=$ & $0 / 100$ & +1.0668 \\
\hline 2460 & 12.62 & 0.172 & $0.8 \mathrm{~mm}$. & $0 / 200$ & +1.1011 \\
\hline 2450 & 13.43 & 0.182 & $0.8 \mathrm{man.}$ & $0 / 200$ & +1.1282 \\
\hline 2440 & 14.26 & 0.193 & $0.8 \mathrm{~mm}$. & $c / 100$ & +2.1535 \\
\hline 2430 & 14.91 & 0.202 & $0.8 \mathrm{~mm}$ & $c / 100$ & +1.1735 \\
\hline
\end{tabular}


Tasti: II (Cont1mod)

\begin{tabular}{|c|c|c|c|c|c|}
\hline $\begin{array}{l}\text { Wetre Ioncth } \\
\text { in } \\
\text { Anestrons }\end{array}$ & Alphs & $\log \frac{I_{0}}{I}$ & $\begin{array}{l}\text { silt } \\
\text { vidth }\end{array}$ & $\begin{array}{l}\text { Concen- } \\
\text { tretion }\end{array}$ & $\begin{array}{l}\text { Iog Spoedifie } \\
\text { IxxtInction } \\
\text { Coefflefent }\end{array}$ \\
\hline 2420 & 15.64 & 0.212 & $0.8 \mathrm{ann}$. & $c / 100$ & $+1.1 \% 42$ \\
\hline 2410 & 16.38 & 0.222 & $0.8 \mathrm{~m}$. & $0 / 100$ & +1.2143 \\
\hline 2400 & 17.12 & 0.232 & $0.8 \mathrm{~m}$. & $c / 100$ & +2.2335 \\
\hline 2390 & 27.86 & 0.2152 & $0.8=$ & $c / 100$ & +1.2519 \\
\hline 2380 & 18.45 & 0.250 & $0.8=$ & $0 / 200$ & +1.2660 \\
\hline 2370 & 19.04 & 0.258 & $0.8 \mathrm{xam}$ & $0 / 100$ & +1.2797 \\
\hline 2360 & 19.50 & c.264 & $0.8=$ & $c / 100$ & +1.2900 \\
\hline 2350 & 29.78 & 0.268 & 0.8 axs. & $c / 100$ & +1.2963 \\
\hline 2340 & 20.00 & 0.27 & $0.8=$ & $0 / 100$ & +1.3010 \\
\hline 2330 & 20.15 & 0.273 & $0.8=$. & $c / 100$ & +1.3043 \\
\hline 2320 & 20.22 & 0.274 & $0.8 \mathrm{~mm}$. & $0 / 100$ & +1.3058 \\
\hline 2310 & 20.25 & 0.273 & $2.0=$ & e/200 & +1.3043 \\
\hline 2300 & 39.78 & 0.268 & $1.0 \mathrm{zm}$. & $0 / 100$ & +1.2963 \\
\hline 2290 & 19.71 & 0.267 & $1.0 \mathrm{man}$. & $0 / 200$ & +1.2947 \\
\hline 2280 & 29.04 & 0.258 & $2.0 \mathrm{~mm}$. & $c / 200$ & +1.2797 \\
\hline 2270 & 28.60 & 0.252 & $1.0=$ & $c / 100$ & +1.2695 \\
\hline 2260 & 18.30 & 0.248 & $2.5=$ & $c / 100$ & +1.2625 \\
\hline 2250 & 17.48 & 0.237 & $2.5 \mathrm{man}$. & $0 / 100$ & $+2.24{ }_{25}$ \\
\hline 22110 & 16.83 & 0.228 & $1.5 \approx$. & $c / 100$ & +2.2262 \\
\hline 2230 & 16.02 & 0.217 & $2.5 \mathrm{man}$ & c/100 & +2.2046 \\
\hline
\end{tabular}


TABTล XI (Continod)

\begin{tabular}{|c|c|c|c|c|c|}
\hline $\begin{array}{l}\text { Wave Jiengthy } \\
\text { in } \\
\text { Anestrons }\end{array}$ & Alphe & $\log \frac{I_{0}}{I}$ & $\begin{array}{l}\text { SH1t } \\
\text { viath }\end{array}$ & $\begin{array}{l}\text { Concen- } \\
\text { tret1on }\end{array}$ & $\begin{array}{l}\text { Iog Specific } \\
\text { Jutinction } \\
\text { Coefficlent }\end{array}$ \\
\hline 2220 & 15.50 & 0.210 & $2.5 \mathrm{~mm}$ & $0 / 100$ & +1.1903 \\
\hline 2220 & 14.98 & 0.203 & $1.5 \mathrm{~mm}$ & c/100 & +2.1756 \\
\hline 2200 & 14.61 & 0.198 & $2.0=$ & $0 / 200$ & -1.1647 \\
\hline 2190 & 13.95 & 0.189 & $2.0=$ & c/100 & +2.1446 \\
\hline 2180 & 13.35 & 0.182 & $2.0 \mathrm{mas}$. & $c / 100$ & +1.1255 \\
\hline 2170 & 12.77 & 0.273 & $2.0 \mathrm{man}$ & $c / 100$ & +1.1062 \\
\hline
\end{tabular}

Some of the data from Fable al 10 presented graphlealjy In rigure 2.

The Speclfie Abroxption Coefrielents found from fable II vere as follove:

At 2310 Arigstrons, the velue obtalned was 20.00 ,

At 2680 Argetroms, the relue obtalned vas 8.18 ,

At 3010 Angutrons, the value obtalned vas 2.90 .

At 3160 Argetrows, the value obtained was 2.61 .

From Mablo IX It wes found thet the above values were oquivalent to the followling pereentages of aolds:

At 2340 Angatroms, 15.4 per eant of Iinoleie acld,

At 2680 Angetroms, 3.9 per cent of 21 nolemie noid,

At. 3010 Angatrons, $21.2 \mathrm{~h}$ per cent of arechidonle seld,

At 3160 Angetroms, 11.57 per cent of axachidonie acid. 


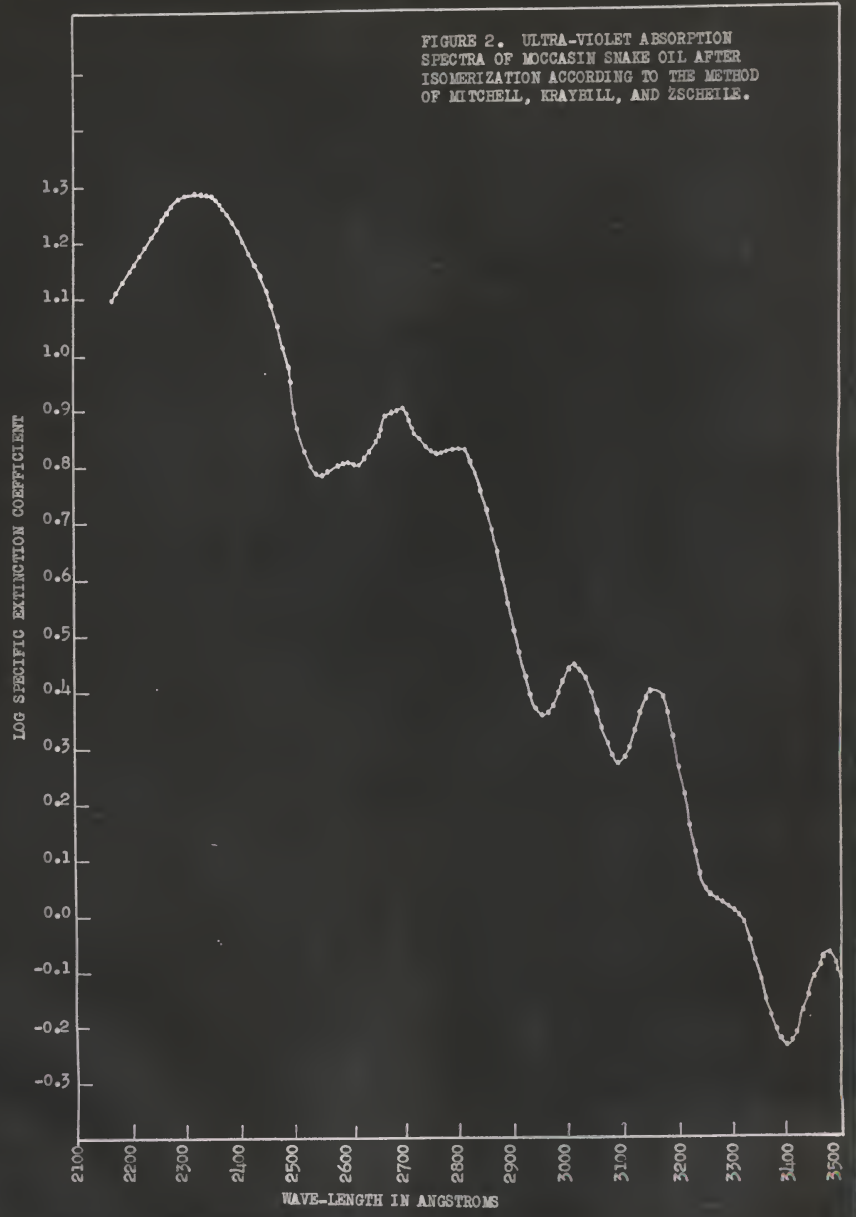


An cramination of the data indicates that the followldg values are nore probaliy correct:

Inolele acid................. 15.4 per cent Arechidonse and cirpanodonie acids.. 11.4 per cent Irom spectrophotometrie dets for the range Iros 2400 to 2800 Angetronil It appeared that the absorption nay have been censed by a vitamin or by vitanin-11/co substences: It is probable that this Is the reason that Hildsteh and shrivastava88 found too hich a value for Inolente acld by the gpectrophotomotrie method. Vitanin D, which contains three couble bonds in conjugated position, world be expected to shor up In this range on the spectrophotometer 9 ?. 
suncurx

The folloving quelltative and quant1tative analyses of moceasin snake oll are based on research reported in this dissertation:

TAFI는 XI

Pexeentage of Fatty Acide in Hoceas in Smalve 011

\begin{tabular}{|c|c|}
\hline Inare of se1d & Percentege \\
\hline Noriatie & 1.77 \\
\hline Ralnitle & 15.93 \\
\hline Stearle & 8.37 \\
\hline Elexadocenole & 6.53 \\
\hline Olele & 35.25 \\
\hline Irnoleic & 15.70 \\
\hline Arachtconte and clupanodonte & 21.28 \\
\hline ToraI & 94.73 \\
\hline
\end{tabular}

Two partial teste of the reliability of this analysis are:

(1) The Iodine Value of the sum of fatty selde Inund as compared to the originel noecasin snaks ofl, and

(2) The saponification equivalent of the ww of the latty acida forma as compared to the orleinal moccasin snolce o1. Fabies XIII and XIV give the results obtalned. 
LARLS XII

Fereentage Corposition and Iodine Valwes of Iatty Leids of Hoecasin Snake 011

\begin{tabular}{|c|c|c|}
\hline Ilame of Aela & $\begin{array}{l}\text { Percentage } \\
\text { of Fotal }\end{array}$ & $\begin{array}{l}\text { Theoretieal } \\
\text { Iodine Value }\end{array}$ \\
\hline verletie & 2.77 & 0.000 \\
\hline Pelnitie & 15.93 & 0.000 \\
\hline Sterarle & 8.37 & 0.000 \\
\hline Hexpdeceriolo & 6.53 & $0.0653 \mathrm{gram}$ \\
\hline Orele & 35.25 & $0.317 \operatorname{gran}$ \\
\hline Inolete & 15.7 & $0.285 \mathrm{grem}$ \\
\hline Arachldoule and Clupanodonie & 21.4 & $0.381 \mathrm{gran}$ \\
\hline MONAT & & 2.048 erans \\
\hline
\end{tabular}

The total Iodine Value of the original moceasin snake oll was 1.071 grama, whlch is 0.023 gxan greater than the total for the aclde. These determinatlons were besed upon a one-grem sanple of the original moceasin snake o11. 


\section{FABR르 XIV}

Pereentage Composition and Saponifleation Iquivalents of the Fatty Melde of Moceasin Snelce 011

\begin{tabular}{|c|c|c|}
\hline Wane of Aatd & $\begin{array}{l}\text { Percentage } \\
\text { of Fotal }\end{array}$ & $\begin{array}{l}\text { Theoretical } \\
\text { Saponiflestion } \\
\text { Ievivelent }\end{array}$ \\
\hline Wyriat1e & 1.77 & 4.4 \\
\hline Palnitie & 15.93 & 34.9 \\
\hline Steerle & 8.37 & 26.5 \\
\hline Elexadeceno $1 \mathrm{c}$ & 6.53 & 24.4 \\
\hline olele & 35.25 & 70.1 \\
\hline Inolese & 15.7 & 32.4 \\
\hline Arachilionle and Clupenodonte & 11.4 & 21.0 \\
\hline nosat & & 192.7 \\
\hline
\end{tabular}

The total moponifieation equivalent of the original moccsain snoke oll wes 192.6, whlch is 0.1 gram less then that of the acids. These calculations were based on a one-gram sauple of the origtnal noccasin snalise oll. 


\section{comcunstors}

Besed upon the dats shown in this dissertation, the following conclusions are indicated:

(1) Eichly unsaturated fatty scica are not eesily distilled, oven at pressures as low as $0.2 \mathrm{men}$. to $0.2 \mathrm{~mm}$.

(2) In speetrophotonetric deternination of latty aclds extrewe eare rast be talcen to ervinate the data obtelned.

(3) In any deternimtion of fatty acida in moccasin mais 011. no single method is absolutely relisbie. 
1. Mcieughilin, J., and Pollerd, C. B., Umpribli whod Data (X.S. Thesia).

2. Touns, D. C., Jr., and Polland, C. B., Tupublished Dats Q. S. Thesis).

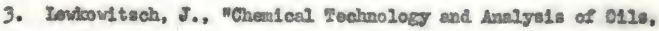
Fate, and Wareos," Volulian and Co., HInted, Vols. 1, 2, 3 (1915), zisth rattion.

4. Grun, A., Analyge ter Pette and Vechge, Vol. I (Ber11n, 1925).

5. Bolton, I. R., "Fats and Patty Food" (Iondon, 1928).

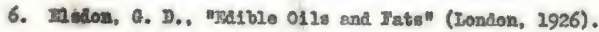

7. Dean, H. T., Wtiligation of Pats" (Iondon, 1938).

8. Il1a1tch, F. P., "Whe Chemleal Constitution of Ilatural Pata" John viley \& Sons, Inc., Firat Bdition.

9. OfPielal and Fentative llethods of Analgsis of the Assoclation of Agriculturel Chemists, sixth saltion (19/5), publishod by the Aswoclation of Official Agricaltural Chentsts, P. 0. Box 540, Benjemin Iranilin Stetion, Vashington 4, D. C.

10. Hilaitch, T. P.. "Mro Chemleel Constitution of Iatural Fats," John V1ley a sons, Inc., Second raition (19h7).

11. Balston, A. W., "Fatty Acide and Their Derivativeq" John Wiley Sons, Inc., (19/48).

12. Narkieg, X. S., "Iatty Ac1as," Inter-Selenee Publishers, Ine., 215 Jourth Arema, Jev Yorix 3, x. Y. (1947). 
13. Traff, Ber... 13, 1/13 (1880); Xraft and Woerd1inger, Ber.. 22, 826 (1889); Xrafft and Dyes, Bor.., 28, 2583 (1895); Irafft and Vellandt, Ber.. 22, 1316 (1896).

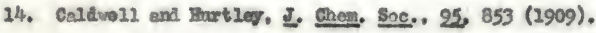

15. Brown, Brac. Ohen. Soc., 26, 149 (1910).

16. Xratt, Ber. 36,4339 (2903).

27. Xxels and Hatwor, Bex., 36,2766 (2903).

18. Ilaller and Toussourian, Cornot. rend., 143, 803 (1906).

19. Bull, Ber.. 32, 3570 (1906).

20. Ilolland, I. Inc. Ine. Chem., 2,17 (1911).

21. Smodley. Blochen. J., 6, 451 (1912).

22. Hollend, Rosd, and Buckioy, I. Ave. Reseerch, 6, 201 (1916); Bolland and Buckley, I. Lex. Pesoareh, 12,79 (1918);

Holland, Garvey. Pleree, Messer, Arohtbald, and Drabar, I. AEz. Reaeeroh, 2h, 365 (1923).

23. Crouther and Hyad, B1ochem. I.. 11, 139 (1917).

24. Channon, Druminond, anll Golaing, Anelrgt. he, 311 (1924).

25. Bosworth and Irovm, I. B101. Chen., 103, 115 (1933).

26. Inscion, Anelyst, 38,8 (1913); 22,78 (1914).

27. Hoyer, Chen,-2tr., 21,793 (1907).

28. Grun, Ghen. Unschan, 26, 101 (1919).

29. Bosworth, I. B101. Chem., 106, 235 (1934).

30. Hashimoto, I. An. Ohen. Soc.. 47. 2325 (1925).

31. Cohon, Veruleg Abod. Vetengcherpen Ansterdan, 24,462 (1925). 
32. Stolcoe, Analyst, 49, 577 (292/4).

33. Armetrone, Ml lan, and Noore, I. Soc. Chem. Ind., 44., 635. 1435 (1925).

34. Drown and Beal. I. An. Ghen. Soc. 45, 1289 (1923).

35. Drown, I. Biol. Ghen., 83, 763 (2929).

36. Jrown and tralt, I. B102. Ohers., 89, 167 (1930).

37. Durton, I. Spe. Ohem. Ind., 38, 45. (1919).

38. Clarice and rahrs, Ind. Ins. Ghen., 15. 349 (1923).

39. Vidnex, Eolv. Ghin. 1ets, 2. 59 (192/).

40. Peters and saker, Ind. 1ne. Ghen., 18, 69 (1926).

41. Cooper and Insco, Ind. Ing. Chenn. 20, 420 (1928).

42. Jantsen and Meacke, J. Dralt. Mhem. (2), 127,277 (1930).

43. Ivans, Cornish, Leplowikg, Archtbald, and Fesloov, Ind. Ine. Whes., Anas. IB., 2. 339 (2930).

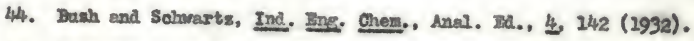

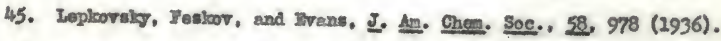

46. Mnstrore and Iux, I. An. Ghen. Soc., Sh, 3448 (1932).

47. VIson, Parker, and lewghlin, J. 새. Ghor. Soc.. 55, 2795 (1933).

48. Veston, Ind. Ins. Chens., Ans. Ia... E, 179 (1933).

49. Fodblelniak, Ind. Ing. Ghen., Anel. St., E 119 (1933).

50. KIen, Nature, 142,616 (1938).

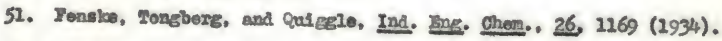

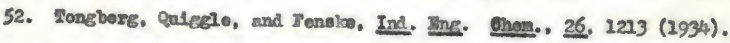

53. Fensive, ช. S. Patent 2,037.317 (2936). 
54. Tongberg, Learsound, and Fensice, Ind. Ing. Chent. 29, 957 (1937).

55. Jenake, Iawrowald, and Tongbers, Ind. ans. Ghem., 30,297 (1938).

56. Schoenheiner and R1ttenberg, I. B101. Cherl., 120, 155 (1937).

57. Longeneciver, 011 and Soge, $1253(1940)$.

58. Stedman, v. S. Patest 2,047,444(1936); Can. Patent 361,043(1936).

59. Stedmen, Uen. I. Research, 125, 383 (1937).

60. Braes, Ind. Ins. Ghems. Anal. Ma., 21, 283 (1939).

61. Tamex and Van den Heuvel, I. 5oc. Ohem. Ind., 2Z. 2/4 (1938).

62. I I B101. Chen.. 139, 199 (2942).

63. Horr1s, I. A., and Ferry, I. I., 011 and soep, 22,41 (1945).

64. Blelecid and Ienr1, Dez.. 46, 1304 (1913).

65. Mamart-inces, Blquard, and Grunteldt, Compt. senc., 190 , 1196 (1930).

66. Blelodid and Henrs, Bex., 4h6, 1304 (1913).

67. Lay and Axends, 2. phyeik. Chen., 173, 177 (1932).

68. Durs and Hiller, Chem. Rer., 22. 221 (1923).

69. Mantzach, 2. Blelstrochem., 29, 221 (1923).

70. Hertleb, Strehlentheranle, 32, 442 (1931).

7. Iradley and Mlchardaon, Ind. Jns. Chers., $22,963(2940)$.

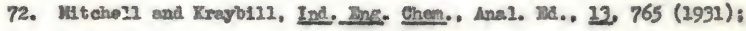

J. 스. ㄱen, Soc.. 64, 988 (1942).

73. Mitchal1, Trasbi11, and Zscho1le, Ind. Ing. Chem., Anel. Id., 15. 1 (1949). 
$-70$

74. Van der Bulst, Bec. trev. chin. 54, 639, 644 (1935).

75. Dingwell and Thomas, I. Am. Chem. Soc., 56, 899 (1934).

76. Bourguel, Grody, and Plewr, Courpt. rend. 195, 129 (1932).

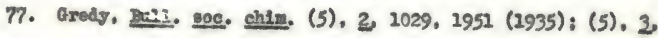
1101 (1936): (5), 4, 415 (2937).

78. Delaby, Plawa, and Guillemonat, Convt. rend., 205, 609 (1937).

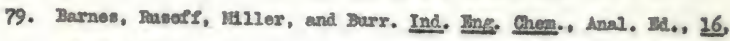
385 (2944).

80. Dusolf. PIatt, Xleverns, and Burx, I. 슨. Chem. Soen 67.673 (1945).

81. Imeors, Folman, and Burr, 011 and Soap, 22, 290 (19/45).

82, Brice, B. A., Swaln, M. I., Scheeffer, B., Aalt, V. C., 02I and Soan, 22, 219 (2945).

83. O'Connor, T. R., Helnselman, D. C., and Dollear, F. A., 011 and Bose, 22, 257 (1945).

84. O'Connor, R. F., HeInselmen, D. C., Gerare1Ia, K., and Bever, 011 and Soep, $23,5(1946)$.

85. Irundberg, V. 0., Holmen, R. F... and Burx, 0. 0., 011 end Soge, 23. $10(1946)$.

86. Flolmen, R. T., Areh. Blochem. 20, 519 (19/4).

87. Boadio, D. W., O1I and soag, 23,140 (1946).

88. M1lattch, \%. P., end Shrivasteva, R. X., Anelvat, 22, 527 (1947).

89. OlConnor, R. P., Helnselmen, D. O., Nerinney, R. S.. and Paok,

7. C.. I. An. 011 Chentstg' Soc., 24, 212 (1947).

90. Hendrickson, M.J., Cox, I. P., and Tonen, J.0.. J. An. 012 
Ohersists' Soc., 25, 73 (1948).

91. Ross, J., ข. S. Patent 2,435.159.

92. Mite, H. J., Oriens, B. K., and Brom, J. B., I. 쇼. 이 Chem1sts' Soc.. 25, 73 (19/48).

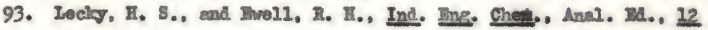
$544(2940)$.

94. Mtehol1, J. I.., Jx., Iregbil1, H. R., and Zsehe110, J., P., Ind. and ing. Ohem., Anal. Ba.. 15, I (19/3).

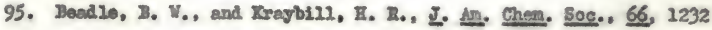

96. Shriner, Maiton, and Durkas, J. An. Chen. Socn 55, 1494 (1933).

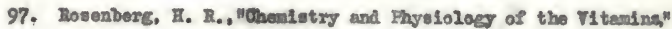

Inter-Seience Publishere, Ine., Iow Yort, I. Y. (1942). 


\section{ACKNOIT EDOHATHS}

The sathor expresses his elncere appreclation to Dr. O. B. Pollard, Chairman of the eathor's Supervisory Connattes, who has directed this senesrch. The nceess of the undertaldng is dwe Iargely to Dr. Pollard's lindness and contructive critlelan.

Sincere appreclation is hereby expressed for the cooperation of $\mathrm{Mr}$. Moss Al lem of StIver Springs. Morida. Mo. Mlen kindy donated the o1ls and rav materials used for this strdy. 


\section{i BIOCRaratcat, Imats}

Joseph Normenglin, Ir., was bom on October 7, 1915, at Varlette, Ohlo. If grarwed his uadergrechete studles at the Inlversity of Fomda, where he recelved his Bachelor of Selence Degree in 1939.

The author's Graduate work at the Univeralty of Iortas was Interrupted by lorty-ilve months service in the Arxy. Thenty monthe of this Arry service wes spent as chemist in the Blologleal. Warfare Project at Camp Detrlok, Naryland. Ile recolved his Naster of Selenee Degree frov the University of Floride in 1947. Intio attending the Grectuate School of the Universify of Floride he held the position of Ieboratory Aseivtant for two yoars and a Creduate Couned I rellowshlp for three years.

He Is a nember of the Americen Chemical Soelety and of rlarlds IIne rog. 
Fhls dissertetion was prepared under the direotion of the Chatruen of the eandidate's supervisory Comittee and has been approved by all wabers of the combttee. It was rabmitted to the Greduate Counell end vas approved as pertsel fulp1 liment of the requircments for the degree of Doctor of Phdiosonhy.

Dato

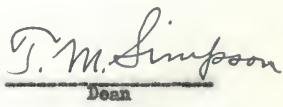

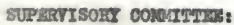
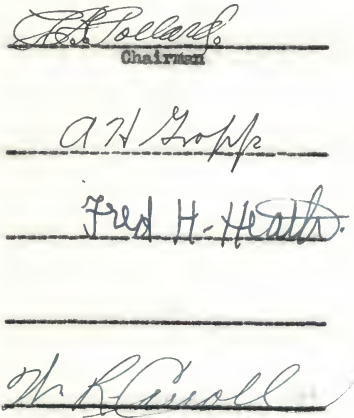